Yılmaz, R., Arslan, S. (2021). “Neoliberalizm, Merkez Bankası Bağımsızlığı ve Baskı Gruplarının Rolü”, Eskişehir Osmangazi Üniversitesi iiBF Dergisi, 16(1), 252 - 275.

Doi: $10.17153 / o g u i i b f .885291$

Başvuru: 23.02.2021

Kabul: 19.03.2021

Araştırma Makalesi/Research Article

\title{
Neoliberalizm, Merkez Bankası Bağımsızlığı ve Baskı Gruplarının Rolü
}

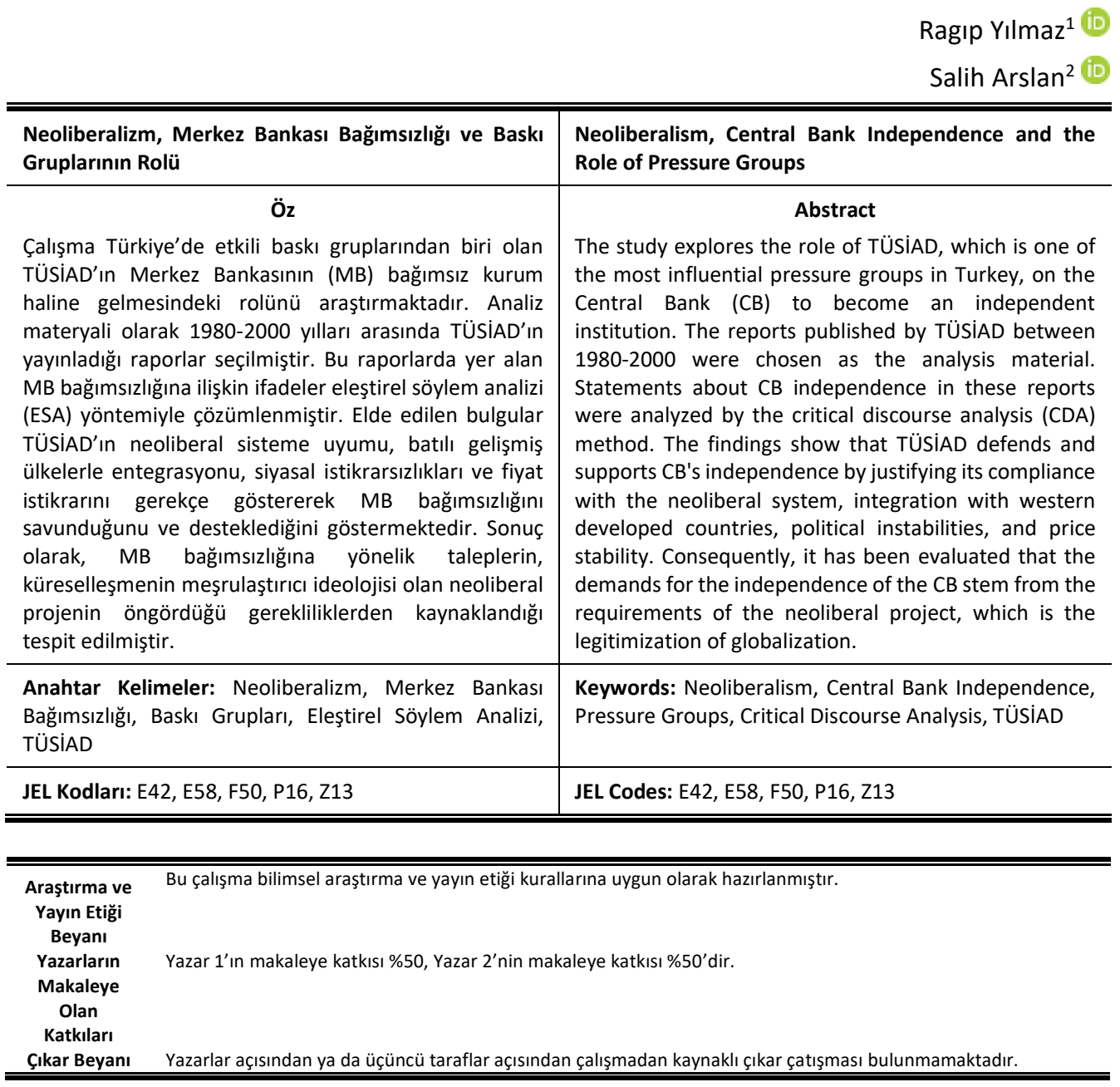

${ }^{1}$ Dr. Öğr. Üyesi, Eskişehir Osmangazi Üniversitesi iïBF, Uluslararası ilişkiler Bölümü, r.yilmaz@ogu.edu.tr

${ }^{2}$ Dr. Öğr. Üyesi, Eskişehir Osmangazi Üniversitesi IiBF, Siyaset Bilimi ve Kamu Yönetimi Bölümü, salih.arslan@ogu.edu.tr 


\section{Giriş}

Kapitalizm 1970'lerdeki petrol krizinden sonra para arzının kontrolü ve kamu harcamalarının sınırlandırımasına dayalı bir dönüşüm sürecine girmiştir. Neoliberalizm olarak adlandırılan bu siyasal, ekonomik ve toplumsal dönüşüm projesinde ülkelerin benzer yapılarla birbirine entegrasyonu hedeflenmektedir. Bu projenin ülkelerden beklentileri arasında devletin ekonomi içindeki payının azaltılması ve işlemlerin piyasaya bırakılması, kamu işletmelerinin özelleştirilmesi, finansal sistemin, dış ticaretin ve sermaye hareketlerinin serbestleştirilmesi, kamu yönetiminde işletmecilik yöntemlerinin uygulanması ve paydaşların katılımına dayalı yönetişim mekanizmalarının etkinleştirilmesi sayılabilir. Piyasaların düzenlenmesi ve denetlenmesi işlevini doğrudan siyasi otoriteye bağlı kamu bürokrasisi değil özerk kurumların üstlenmesi önerilmektedir. Bu doğrultuda para piyasasını yönlendirici politikaları oluşturan merkez bankasının (MB) bağımsız bir yapıda olması ve siyasetin etkisinden uzak kararlar alabilmesi istenmektedir. Siyasi iktidarın yetki ve imkânlarını kısıtlayan bu önerilerin siyaset, ekonomi ve toplumsal aktörler tarafından kabul görmesi ve benimsenmesi için yerel baskı gruplarının aracı rolüne ihtiyaç duyulmaktadır. Türkiye'de toplumsal ve ekonomik dönüşümün gerçekleşebilmesi için aktif bir şekilde çaba gösteren baskı gruplarının başında Türkiye Sanayici ve İş Adamları Derneği (TÜSIAD) gelmektedir.

Bu çalışmanın konusu, MB'nın bağımsız bir kurum haline gelme sürecinde TÜsíAD'ın sergilediği tutum ve ürettiği söylemlerdir. Çalışma TÜsiAD’ın söylemlerindeki gömülü niyetin ya da alt anlamların neoliberal ideoloji ile ilgisini sorgulamaktadır. Çalışmanın amacı TÜSiAD’ın MB bağımsızlığı konusundaki söylemleri ile neoliberalizm arasındaki ilişkiyi ortaya çıkarmaktır. Bu amaçla TÜSiAD'ın 1980-2000 yılları arasında yayınladığı raporlar analiz materyali olarak seçilmiştir. Bu raporlarda geçen MB bağımsızlığına yönelik ifadeler eleştirel söylem analizi (ESA) yöntemiyle çözümlenecektir. Bu doğrultuda öncelikle neoliberal düşünce teorik ve kavramsal açıdan incelenecek, sonra MB bağımsızlığına yönelik tartışmalar ele alınacaktır. Son kısımda TÜSIAD'ın raporlarında yer alan $M B$ bağımsızlığına yönelik ifadeler ESA yöntemi ile çözümlenerek, ulaşılan bulgular araştırmanın amacı ve sorusu çerçevesinde değerlendirilecektir. Çalışmanın Türkiye'de MB bağımsızlığını neoliberalizm bağlamında ele alması ve baskı gruplarının bu süreçteki rolünü göstermesi bakımından literatüre katkı yapması beklenmektedir.

\section{Neoliberalizm ve Devletin Dönüşümü}

Dünya ekonomisi kabuk değiştirdiği dönemlerde, devletlerin yanı sıra ekonomi ile ilişki içinde olan toplumsal, siyasal, kültürel yapılar bu değişim sürecine uyum sağlamaya çabalamış ve kurumsal dönüşümler içine girmiştir. Her dönüşüm süreci, yeni bir hegemon ideoloji ve bu ideolojiyi destekleyen teorileri, ekonomiden siyasete bütün yapıların dönüştürülmesinde yol gösterici kabul etmişlerdir. II. Dünya Savaşı'ndan sonra yol gösterici kabul edilen Keynesyen teorinin egemen olduğu bu süreç, 70'li yıllardaki petrol krizine kadar devam etmiştir. Bu dönemden sonra dünya, teorik izleri klasik liberalizm ve neoklasik iktisat düşüncelerinde yer alan, ama kendisini yeni olarak tanımlayan neoliberalizm ve neo-muhafazakâr düşünceler etrafında (Tok, 2014: 129) tarihte ilk defa üretimin, pazarlamanın ve yatırımın küresel ölçekte organize edilmesinin de önünün açıldığı (Gilpin, 1975: 39) II. Küreselleşme dönemini (Mishkin, 2009: 143; Yeldan, 2013: 15) yaşamaya başlamıştır. Bu süreç yaklaşık olarak 1820-1914 yılları arasında dünya ekonomisinde ilk küreselleşme evresi (Baldwin ve Martin, 1999; Bordo vd., 1999; Williamson, 2002; Rodrik, 2011: 21; Acemoğlu ve Robinson, 2012: 40; Clark, 2013: 329;) 
olarak kabul edilen evreden özellikle sermaye hareketlerinin serbest olmasıyla farklılaşmış ve günümüze kadar gelmiştir.

Keynesyen ekonominin temelinde, klasik liberal ve neoklasik yaklaşımların kabul ettiği rasyonel bireyler tarafından Adam Smith'in görünmez eliyle ortak çıkarlara uygun faaliyetlerin yerine getirilmesi ilkesi yer almaz. Bunun aksine Keynes, ekonomik faaliyetlerin büyük kısmının "hayvansal güdüler" tarafından yönlendirildiğini iddia etmekteydi. Bunun için Keynes, kapitalizmi istikrarsızlaştıran ekonomi dışı hayvansal güdüleri kontrol etmeyi amaçlamıştır (Akerlof ve Shiller, 2010: 13). Adeta Giambattista Vico (2007) tarafından günah olarak kabul edilen duygular ekonomik gelişmenin öncüsüyken, kontrol edilmeleri ise Keynes için önemliydi.

Aslında Keynesyen ekonominin çöküşünde 70'li yıllardaki petrol krizine vurgu yapılmasına karşılık, çöküşün temelleri 1965-73 yılları arasındaki kapitalizme ve Fordist üretime ilişkin kalıtsal iç çelişkilerin varlığından kaynaklanmıştır. Denetim altında tutulamayan bu iç çelişkilerin ortaya çıkmasındaki temel neden, sistemin bünyesinde barındırdığı talep artışına odaklı büyük ölçekli yatırımlarda tasarım esnekliğinin yokluğu ve emek piyasasında iş sözleşmelerinin varlığı yanı sıra emek hareketliliğinin olmamasından kaynaklanan "katılıktır". Bu dönem içinde katı olmayan tek esnek politika aracı para politikasıydı (Harvey, 2010: 165).

Keynesyen döneme ait katılıkları ortadan kaldırmak amacıyla, refah devleti uygulamaları geri plana itilmiş, buna bağı olarak toplumsal uzlaşıyı ve sosyal hakları öne çıkaran ve sistemin esnekliğini kaybettiren politikalar önemini kaybetmiştir. Bunların yerine 1938 yılında Walter Lippmann Kolokyomunda liberalizmi yenileme düşüncesi etrafında kullanılan neoliberalizm kavramı (Slobadian, 2020:15), 1947 yılında kurulan Mont Pelerin Cemiyeti'nin, monetarist yaklaşımın (Friedman, 1963) ve Schumpeterci Çalışma Devleti'nin (Jessop, 2000; 1996; 1994) düşüncelerini esas alarak, "tarihin sonuna" (Fukuyama, 1989; 1999) yaklaşmayı sağlayacak politikaları devreye sokmuştur. Bütün bu yol haritası sonucunda, yeni bir planın mükemmel bir şekilde işlemesi için gerekli olan kurumsal çöküş de gerçekleştirilmiştir (Parkinson, 1957: 60).

Bu üç düşünceyi temel alan bu dönem, 90'lı yıllardaki Washington Uzlaşısı (Williamson, 1993) ile birlikte devleti ekonomi politikalarından geri çekerek, piyasa önderliğindeki politikalara öncelik verilmesini tavsiye etmiştir. Washington Uzlaşısı tam işleyen piyasalar teoremine dayanmaktaydı (Wagenberge 2009: 318). Dolayısıyla kaynak tahsisi görevi serbestleştirme amacıyla piyasaya bırakılırken, devletin bu sistem içindeki tek meşru görevi, oyunun kurallarını belirlemek şeklinde ifade edilmiştir (Lall, 2009: 459). Devlet Keynesyen dönemde, adeta bir ebeveyn gibi sahneyi hazırlayıp hayvansal güdülerin neden olacağı aşırılıklara karşı önlem almaktayken; neoliberal dönemde ise devletin rolü değişmekte, mutlu yuva kavramı hoşgörülü ebeveyn tarafından ele geçirilmektedir (Akerlof ve Shiller, 2010: 1415).

Ayrıca bu dönemde neoliberal yaklaşım, görünmez el ilkesini yol gösterici kabul etmiştir (Stiglitz, 2009: 296). Böylece görünmez elin yönlendirdiği neoliberal politikalar üzerinde sağlanan uzlaşı, dünya ekonomisinde "iyi politikaların" neler olduğuna dair çerçeveyi sunmuştur. "İyi politikalar" olarak nitelendirilen bu politikalar, makroekonomi politikalarının, yatırımların ve dış ticaretin serbestleşmesini, özelleştirmelerin teşvik edilmesini ve devlet düzenlemelerinin azaltılmasını içermiştir. Bununla birlikte iyi politikaları destekleyecek ve gerçekten iyi politikalar olmasını sağlayacak "iyi kurumların” da oluşturulması gerekliliğini öne çıkarmıştır. Bu sayede dünya ekonomisinde egemen yapı içinde iyi sonuçlar alınması mümkün olacağı ileri sürülmüştür (Chang, 2009: 58; Wagenberge, 2009: 315; Huber ve Stephens, 2013: 791). Diğer bir ifadeyle vatandaş odaklı devlet yapısına meydan okunmaya başlanmıştır 
(McMicheal, 2013: 767). Bütün bunların sonucunda "çift yönlü" (Polanyi, 1944) hareketlerle son 150 yıllık süreçte elde edilen toplumsal ve siyasal kazanımlar da ortadan kaldırılmıştır. Böylece ulusal kalkınmayı hedef alan politikalar geri plana itilirken, devletin ekonomiye müdahale etmesinin önüne geçilmiş, bürokratların ve politikacıların rant peşinde koşması engellenmek istenmiştir (Öniş ve Şenses, 2009: 347-348).

Devletin küçülmesini öngören küreselleşme devlete tamamen karşı değildir. Hatta gölge bir devlete ihtiyaç duyar. Bunun temel nedeni devletler, ticarete daha bağımlı hale gelirken, sivil toplum ve şirketlerle iş birliği içine girerler (Evans, 1997). Nitekim şirketler de içerisinde faaliyet gösterdikleri devletlerin, var olan sistemden ayrılmamasını istemişlerdir (Arrighi, 1990: 371). Hatta devletler küreselleşmenin taleplerini yerine getiren aracı bir rol üstlenmiştir. Diğer bir ifadeyle, kapitalizm büyük pazarlara ihtiyaç duyarken, bu pazarların düzenlenmesi görevi devlete bırakılmıştır. Bundan dolayı küresel sistem, devletlerin ortadan kalktığı görüşünün aksine (Vernon, 1971; Gilpin, 1975; Kennedy, 1993; Rodrik, 1997; March ve Olsen, 1998), kendi varlığına destek verecek birçok devletin var olmasını teşvik etmiştir. Ayrıca tek bir devletin hegemon olduğu Keynesyen dönemden farklı olarak, küresel sistemin dayandığı neoliberal ideolojinin temel savunucusu olarak uluslararası kurumlar inşa edilmiştir. Gevşek bağlar ile birbirine bağlı uluslararası kurumlar, kapitalizmin sonsuz sermaye birikimine yönelik yolu açarken, devletler içinde bu modeli destekleyecek kurumsal dönüşümlerin de önderliğini üstlenmiştir (Wallerstein, 2005: 46-47). Bu yönleriyle değerlendirildiğinde devletler bu süreçte güç kaybetmemiş, aksine birincil aktör olarak toplumsal sorunların belirlenmesinde ve yönetiminde aktif rol almışlardır (Meyer, vd., 1997: 157). Dolayısıyla küresel alan, devletlerin oyun oynadıkları alanda, oyunun gerçekleştirilmesinde güç kazandığı bir alan olmuştur (Polillo ve Guillen, 2005: 1765-1766). Bu noktadan değerlendirildiğinde devletler ortadan kalkmamakta, ancak işlevleri değişmektedir (Özdemir vd.; 2015: 34-35).

Değişen işlevler nedeniyle ortaya çıkan sorunların çözümünde ve küreselleşmenin hızının yönetilmesinde uygun yönetişim mekanizmaları devreye sokulmuştur (Bhagwati, 2009). Raymond Aron'un "evrensel bilincin toplumu" şeklinde ifade ettiği yeni yapı (Hoffman, 2014: 133), "dünyanın yeni bir aklı" (Dardot ve Laval, 2012) etrafında oluşturulma sürecine girmiş ve yeni uluslararası normlar toplumsal norm haline gelmiştir (Finnemore ve Sikkink, 1998: 893). Bunun yerleşebilmesi ve neoliberal düşünce etrafında küresel etkinliğin tesis edilebilmesi için bütün devletlerin ve ekonomik aktörlerin uyacağı kurallar demeti belirlenmiştir. Böylece oluşturulan kurumlar aracılığıyla değerlerin insanlar tarafından içselleştirilmesi ve topluluk olarak kendi kendilerini ve düşüncelerini değiştirmesi hedeflenmiştir (Chang ve Evans, 2009: 621-624). Dolayısıyla neoliberalizm, yerelden küresele kalkınma süreçlerini yönlendiren ekonomi politiğe hükmeden yapılardaki, kurumlardaki ve normlardaki geniş kapsamlı değişimlere yönelik taleplerle ilişkilendirilmiştir (Kashwan, vd., 2019: 133). Kurumsal benzeşmenin devletlerarasında tesis edilmesi, hegemonik olmayan iş birliğinin önünü açmış ve bu iş birliği uluslararası sistem tarafından da kolaylaştırılmıştır (Keohane, 1984: 50). Böyle bir devletler sisteminin dünyada hâkim olması, devletler içindeki egemen sınıfların ya da diğerlerinin davranışlarını ve tercihlerini de etkilemiştir (Scokpol, 1985: 26). Dolayısıyla dünyada geçerli kültürel ve ilişkisel süreçlerin inşa ettiği devletler (Meyer vd, 1997), küresel değişimlere uyum sağlama çabası içine girdiklerinde sadece kendi dönüşümlerinin bir aktörü değil, aynı zamanda küresel gelişimin en önemli kaynakları haline gelmiştir (Cerny, 1994: 321).

Dünya sistemi içindeki her devlet, bu yeni düzene uygun politikaları uygulamaya koymuştur. Devletleri bu tercihe zorlayan en önemli değişim finansal hareketlerin önündeki engellerin 
kaldırılmasıdır. Finansal piyasaların serbestleşmesi, devletlerin makroekonomi politikalarının uluslararası koordinasyonunu gerekli kılmış (Webb, 1991), ulus devletlerin etkinliğini fazlasıyla etkilemiş ve esnek birikim sistemlerinin temelini atmıştır (Arrighi, 2000: 18-19). Adeta Friedman'ın ifade ettiği şekliyle teknolojinin, finansın ve bilginin "demokratikleşmesi" gerçekleşmiş (Keohane ve Nye, 2014: 105), otoritenin devlet ve özel sektör arasında paylaşıımasına neden olurken (Germain, 2009), politikacıları sınırlandırmış ve devletlerin ülke içinde politik kararlarını kısıtlamıştır (Cerny, 1994; Andrews, 1994). Bunun için de kesin bağıntılar içinde gelecekteki belirsizliği azaltmaya çabalayan, kural temelli para politikaları ve bu politikaları uygulayacak bağımsız merkez bankaları vurgulanmıştır (Rodrik, 2009: 178). Bu yönüyle iktidarı ekonominin seçkinlerine verip sermaye birikimini tesis etmeyi amaçlayan bir siyasi proje olarak neoliberalizm (Harvey, 2015: 27), paranın yönetiminde siyasal yapıları dışlamakta ve teknokratları öne çıkarmaktadır.

\section{Merkez Bankası Bağımsızlığı ve Baskı Grupları}

Merkez bankalarının bağımsızlaşmaları, dünya ekonomisinde devletlerin başka siyaset biçimlerini kabul etmelerinin bir göstergesi olarak düşünülebilir. Bunun temel nedeni hükümetlerin kendi şartlarına göre uygulayacakları politikalardan vazgeçmeleridir. Bu ise günlük hayatın içinde sadece alış-verişi kolaylaştıran bir nesne olarak değerlendirilen paranın görünmeyen yönleriyle çok fazla etkiye sahip olduğuna işaret etmektedir. Elden ele dolaşması nedeniyle takas işlemlerini kolaylaştıran bir nesne olarak görülmesine karşılık, kendisinin görünmeyen kısmında çok farklı anlamları barındırır. Gilpin (2011:152) tarafından ifade edildiği gibi "her uluslararası para sistemi, belirli bir siyasal düzene dayanır". Dolayısıyla para, her ülkenin kendi şartları bağlamında siyasal söylemleri içerirken, aynı zamanda uluslararası politik ekonomi ilişkilerini yansıtan bir niteliğe sahiptir.

Uluslararası politik ekonomide hâkim konumda olan neoliberalizm, teorisiyle pratiği yönlendirirken (Chari ve Kehoe, 2006) para politikalarını, siyasetten ve işsizlik gibi toplumsal taleplerden uzaklaşan (Goodfriend, 2007: 48) sadece enflasyonu öncelikli hedef olarak kabul eden (Alesina ve Stella, 2010) bağımsız merkez bankalarına devretmiştir. Artık yeni bir para politikası, paraya atfedilen nötr olma özelliği etrafında kurgulanarak, neoliberal hâkim ekonomik yapının kurumsal yapılanmasının temelleri atılmıştır (Saad-Filho, 2018: 101). Buna bağı olarak devletler kendi sınıları içindeki paranın kullanımı ve dolaşımı üzerindeki kontrolü yitirmeye başlamış ve piyasayı korumaya veya desteklemeye yönelik politikalara yönelmiştir (Cohen, 2008: 225). Bunun için de yeni para ve kur politikaları, yeni bir makroekonomik uzlaşmayı da beraberinde getirmiştir. Varılan uzlaşma enflasyon hedeflemesini, MB bağımsızlığını ve dalgalı döviz kurunu içermekteydi. Bir yönüyle "imkânsız üçleme” (Mundell, $1962,1963,1964)$ sorununu ortadan kaldırmayı hedefleyen bu uzlaşı, düşük enflasyon odaklı politikaların bütün ülkelerde içselleştirilmesini kapsamaktaydı. Böylece para politikası toplumsal meselelerde nötrleşirken paranın siyasal etkenlerden uzak tutulması tercihi, devletlerarasında politik yakınsamanın bir şartı olarak devreye sokulmuştur (Arestis ve Sawyer, 2003). Politik yakınsamanın sağlanmasındaki temel şartlar, kurumsal düzenlemelerin yanında zamanın ve geleceğin belirli hale getirilip yönetilmesini içermekteydi.

Özellikle gelecekle ilgili politikaların kamuoyu nezdinde geçerlilik kazanabilmesi ve ekonomik aktörlerin yanılgıya düşmelerinin engellenmesi "zaman tutarlılığı dengesinin" (timeconsistent equilibrium) elde edilebilmesine bağlıdır (Lucas, 1976; Kydland ve Prescott, 1977; Barro ve Gordon, 1983). Politikalarında zaman tutarsızlığına düşen ve enflasyona neden olan hükümetlerin engellenmesi için merkez bankalarının siyasal etkenlerden uzaklaştırılması öne 
çıkarılır. Dolasıyla bağımsız merkez bankaları, uzun vadede düşük enflasyon düşük işsizlik oranıyla çok önemli birer istikrar sağlayıcı olur (Hall ve Franzese, 1998; Broz, 2002; Clark, 2002: 736, O’Mahony, 2007). Bağımsız merkez bankalarını inşa ederek hükümetler, zaman tutarsızlığı sorununa (time-inconsistency problem) çözüm bularak, ülke içinde ve uluslararası piyasalarda kredibilite kazanırlar. Bu sayede dünya ekonomisine uyum sağlama göstergesini edinmek yoluyla, dış piyasalardan yeni kredi elde etmeleri kolaylaşır (Tavlas, 1993: 676).

Merkez bankalarının yönetimleri siyasal etkenlerden bağımsız hale geldikçe, hükümetler para politikaları üzerindeki etkisini kaybeder. Para politikalarının bağımsız bir kuruluşa devredilmesi, anti-enflasyonist politikaların izleneceğinin kamuoyuna bildirilmesi anlamına gelir. Hükümetler, fırsatçı bir şekilde ekonomiyi etkileme aracından mahrum kalırlar. Buna karşılık, uzun vadede ekonomik istikrarı temin edecek bir politika aracına sahip olurlar (Bernhard vd., 2002: 705; Corden, 2003: 26-27; O’Mahony, 2007: 809). Diğer taraftan ülkeler merkez bankalarının bağımsız olmasıyla kredibilite kazanıp zaman tutarsızlığı sorununa çözüm bulmaya çabalarken, şeffaf ve hesap verilebilir kurumsal düzenlemeleri de tesis ederler (Dinçer, 2004: 97). Böylece ülkedeki özel sektörün desteğini kazanabilirler (Crowe ve Meade, 2008). Para politikasının yönetiminde yapılan bu düzenlemeler, dünya ekonomi politiğine uyumu amaçlarken, paranın kural temelli politikalar etrafında yönetilmesini gerekli kılar. Merkez bankaları siyaset etkisinden arınırken, enflasyon hedeflemesi ve fiyat istikrarı kurumun öncelikli amacı olur (Chari ve Kehoe, 2006: 12). Bütün bu tercihler bankanın işsizlik gibi toplumsal sorunlara çözüm bulma amacından uzaklaşmasına ve siyasetçilerin istihdam gibi toplumu ilgilendiren temel ekonomik kararlar üzerindeki politika güçlerinden vazgeçmelerine yol açar (Miller, 1998: 434).

Hükümetlerin uluslararası piyasalarda kredibilite kazanabilmeleri ve bu amaçla siyasal etkenlerden bağımsızlaşmalarının tesis edilmesi için merkez bankalarının bağımsızlığı yasalar ile garanti altına alınmalıdır. Bankanın yasal yönden bağımsız olmasındaki temel etken ise banka yönetiminin görev süresinin ve atanmasının siyasal karar mekanizmasının dışında gerçekleşmesidir. Bununla birlikte para politikaları yasal çerçevede açık bir şekilde ifade edildiğinde, hükümetlerin yapmış oldukları borçlanmaların ve harcamaların finansmanının banka tarafından yapılması engellenmiş olur (Crowe ve Meade, 2007: 70; Berument ve Neyaptı, 1999). Özellikle sanayileşmiş ülkelerde yasal yönden bağımsız MB ve enflasyon arasındaki ilişkinin incelendiği çalışmalarda, aralarında ters yönlü bir ilişkinin varlığı ortaya konulmuştur (Alesina, 1988; Grilli, vd., 1991; Cuikerman, 1992; Cuikerman, vd., 1992).

Ayrıca yasal mevzuat ve uygulama arasında farklılık olmaması gerekir. Her iki durum arasında farklılık olması bankanın bağımsızlığını zorlaştırmaktadır (Cuikerman, 1994: 1439). Özellikle bu hukukun üstünlüğü anlayışının tam yerleşmediği ülkelerde ortaya çıkabilmektedir (de Haan vd., 2018: 186-187). Bundan dolayı yasal bağımsızlık yanında fiili bağımsızlı̆̆ı sağlayan açık kurumsal düzenlemelerin varlı̆̆ına ihtiyaç duyulur. Burada fiili bağımsızlığı temin eden en önemli politik uygulama enflasyon hedeflemesi programlarının yürürlüğe konulmasıdır (Cukierman, 2008: 725, Blancheton, 2016: 104). Diğer yandan merkez bankalarının bağımsızlığı ile siyasi istikrarsızlıklar arasında doğrudan bir ilişki söz konusudur. Eğer ülkelerde iktidar sürekli değişirse, hükümetlerin görev süreleri kısa olursa, demokratik yapılardan otoriter yapılara doğru bir kayma olursa ve otoriter yönetimi destekleyen yasalar oluşturulursa ülkeler siyasal istikrarsızıı ile karşı karşıya kalırlar. Dolayısıyla bu istikrarsız dönemlerde bankanın bağımsız olması, para politikasında enflasyonist politikaların uygulanmasını zorlaştırır (Cuikerman ve Webb, 1995: 401). 
Küreselleşme ve onun arkasındaki ideoloji neoliberalizm, merkez bankalarını bağımsızlaştırarak siyasal ve toplumsal yapılanmada güç kaymasına yol açar. Güç kayması zayıf devletlerden güçlü devletlere, devletlerden piyasalara ve emek piyasalarından finans piyasalarına gerçekleşirken (Guillen ve Polillo, 2005: 1766), politikadaki güç kayması ise sanayi ya da çalışma bakanlıklarından ekonomi bakanlığı ve MB'na doğru olmuştur (Cox, 1992: 31). Diğer yandan devlet, birbirinden farklı siyasal ve sosyal grupların, güç ve etki için rekabet ettiği bir kurum olduğundan (Skocpol, 1985) çok farklı sosyal-siyasal grupların ve ekonomik aktörlerin içinde rol aldığı çokbiçimli (poliformik) kristal (Mann; 1993) niteliğe sahiptir. Merkez bankalarının bağımsız olması, toplumsal ilişkilerdeki gücün ekonomi yönetiminde etkin güç kazanan teknokratların ve finansal çıkar gruplarının elinde yeniden merkezileşmesi anlamına gelir (Polillo ve Guillen, 2005: 1769; Posen 1998).

Bunda etkili olan şey ise paranın, siyasal güç dağılımını etkileyen bir işleve sahip olmasının yanı sıra sistemin içinde yer alan toplumsal aktörler açısından düzenin devam ettirilmesinde ya da yıkılmasında etkinliği olan bir araç olmasıdır. Doğası gereği sübjektif olan paranın değeri ve anlamı kalıtımsal değildir. Hem toplumsal hem de siyasal güç aracılı̆̆ıla inşa edilir (McNamara, 2008: 441). Para sosyal yapılar içinde temellendiğinden karşılıklı güvene dayalı ve ağların işlediği yapılar içinde anlamını kazanan bir araçtır. Bunun için grupların kendi içinde ve grupların siyasetle ilişkisinde karşılıklılık ve güven ilişkisi paranın kurumsallaşmasındaki asıl etkendir (Cohen, 1998: 12-13). Özellikle gelişmekte olan ülkelerde ekonomik krizler, sadece belirli politik yapılardaki farklı toplumsal aktörlerin tercihlerindeki değişimi yansıtmaz. Aynı zamanda bu aktörlerin farklı düzenlemeler arasındaki tercihlerini ve mevcut kurumların değiştirilmesine yönelik toplumsal/siyasal güçlerini de etkiler ve ortaya sürer. Ekonomik kriz dönemlerinde özel sektör bir şekilde politik yapılarla pazarlık içerisine girer. Bu pazarlık sürecinde sermaye ve siyasal iktidar arasındaki pazarlık başarısızlıkla da sonuçlanabilir. Diğer taraftan toplumda iktidara yönelik tepkilerin oluşması ihtimali ve paylaşıma yönelik tepkiler, sermaye ve iktidar arasındaki pazarlıkların son bulmasına neden olabilir (Haggard ve Kaufmann, 1995: 7). Dolayısıyla merkez bankalarının bağımsız olmasının değerlendirilmesinde baskı gruplarının kendi aralarındaki ve baskı grupları ile hükümet arasındaki koalisyonun dikkate alınması gerekir (Goodman, 1991: 330). Teknokratların yönettiği bir ekonomi politikası, ülke içinde sosyal çatışmayı sonlandırmanın bir aracı şeklinde değerlendirilir (Centeno, 1993). İktidar ile uyum içinde olan bu gruplar, adeta toplumun elitleri rolüne bürünerek yeni düşünce etrafında şekillendirilen programların ve kurumsal yapıların kamuoyuna kabul ettirilmesinde önemli paya sahip olur (Campbell, 1998).

Baskı grupları ve politikacılar arasındaki birçok gizli ya da açık politik anlaşmalar sübvansiyonlar, transfer ödemeleri, belirli vergi kuralları ve yapısal düzenleme biçimlerinden etkilenen nominal fiyatlara bağlıdır. Bunun için de baskı gruplarının kendi aralarındaki ve siyasetçiler ile yaptıkları koalisyon, politik tercihler neticesinde ortaya çıkan beklenmedik enflasyon nedeniyle çözülebilir (Miller, 1998: 435). Bundan dolayı ülkelerin içindeki baskı gruplarının tercihleri, paranın rolü ve para politikasının nasıl yönetilmesi konusunda farklılaşır. Ülke içinde üretim yapıp, buradaki koşullardan daha fazla etkilenecek sektörler, paranın yönetiminde siyasetin etkin olması gerektiğini savunurlar. İthal ikameci sektörler, ticarete konu olmayan mallar üreten sektörler ve emek sınıfı paranın yönetiminin teknokrat yapılara yönelmesine izin vermek istemezler. Bu gruplar, daha fazla ülkenin içinde bulunduğu makroekonomik koşullardan etkilenmeleri nedeniyle, daha fazla gelir politikasına önem verirler. Bunların aksine dışa açık ekonomik koşullarda iş yapan ve dünya ekonomik 
sistemindeki gelişmelerden daha fazla etkilenen gruplar ise kural temelli ve kesin bağıntılar içinde tanımlanan para ve para politikasını tercih ederler. İhracata yönelik faaliyette bulunan sektörler, uluslararası yatırımcılar, bankacılık ve finans sektörü ve sermaye kesimi, teknokratların yönettiği, siyasetten bağımsız ve birincil önceliği enflasyon hedeflemesi olan bağımsız MB'nı destekler (Bearce, 2003: 378).

\section{Metodoloji}

Çalışmada MB’nın bağımsızlığında baskı gruplarının rolü neoliberal dünya sistemi projesiyle ilişkisi çerçevesinde incelenmektedir. Baskı grubu olarak TÜsiAD ve analiz materyali olarak TÜSiAD’ın raporlarının seçilmesinde amaçlı örnekleme (purposive sampling) kullanılmıştır. Raporlar ESA yöntemiyle çözümlenmiştir. Söylem analizi, kelimelerin biçimi veya yapısı, bağlam içinde dilin kullanımı ve söylemsel pratiklerin anlamları veya yorumlanmasını içeren bir çeşit kelime ve anlam incelenmesi olarak tanımlanabilir. Birçok gelenekteki sosyal bilim araştırmacıları tarafından bir yöntem olarak kullanılmaktadır. Fransız yapısalcıları söylemin telaffuzuna, söylem türlerine ve sosyal şartlara odaklanır. Sosyal inşacı ve fenomenoloji teorisyenleri dilin kullanımından doğan öznel ve özneler arası anlamı araştırır. Eleştirel kuramcılar söylemin hegemonya, örtük denetim ve ideoloji yoluyla farklı sesleri bastırmadaki rolünü vurgular. Postyapısalcılar kelimelerin ve metinlerin sabit veya durağan anlamları olmadığını iddia eder. Yapı-söküm geleneğinde ise metinleri parçalara ayırarak sözcüklerin ve zıtlıkların özel ve gizli yönlerini incelemede önemli bir bileşendir (Putnam ve Fairhurst 2001: 7879). Eleştirel söylem analizi (ESA) ise söylem analizinin bir türüdür ancak ondan ayrı bir yöntemdir (Fairclough, 2001: 121-122). Metin, konuşma, sözlü etkileşim ve diğer iletişim biçimlerinin yapı, strateji ve diğer özelliklerini (Van Dijk, 1993: 250) bağlam temelinde inceler (Meyer, 2001: 15). Özellikle dil ve güç arasındaki ilişkiye odaklanarak; gücün suistimalinde, tahakkümün ve eşitsizliğin yeniden üretiminde söylemin rolünü (Van Dijk, 2001: 96; 2015: 466) ve güç, kontrol, ayrımcılık ve baskı gibi açık yapısal ilişkiler kadar görünmeyen alt ilişkileri de açığa çıkarmaya çalışır (Wodak, 2001a: 1-2).

ESA tek bir yöntem değildir ve farklı yaklaşımlar söz konusudur (Meyer, 2001: 14). ESA'da dört temel yaklaşım ön plana çıkmaktadır. Bunlar Wodak'ın söylem-tarih yaklaşımı (Wodak 2001b), Van Dijk'in sosyo-bilişsel çözümlemesi (Van Dijk, 2001; 2008; 2009), Van Leeuwen'ın sosyal semiyotiği (Van Leewuen, 2008; 2015) ve Fairclough'un diyalektik ilişki yaklaşımıdır (Fairclough, 2003; 2013). Wodak (Wodak ve Reisigl, 2001; Wodak, 2001b) kimlik, ideoloji, ayrımcılık, ırkçıık gibi sosyal ve politik tavırların tarihsel süreç içerisindeki oluşumunu açıklamaya çalışır. Van Dijk (2001; 97) multi disipliner bir yaklaşımla söylem, bireysel biliş ve sosyal biliş arasında kurduğu ilişki üzerinden toplumun bilişsel, kültürel ve iktidar yapılarını ortaya çıkarmaya çalışır (Van Dijk, 2008; 2009). Van Leeuwen (2008; 2015) toplumsal anlamın şekillendiricisi ve aktarıcısı olarak sözlü ve görsel söylem stratejilerinin nasıl üretildiğine odaklanır. Fairclough $(2003 ; 2013)$ ideoloji, güç ve egemenlik ilişkilerini söylem üzerinden göstermeye çalışır. Ona göre söylem iktidar ilişkilerinin üretilmesi, sürdürülmesi ve dönüştürülmesinde başlıca araçtır. Söylemler sadece dünyayı olduğu gibi temsil etmekle kalmaz, aynı zamanda yansıtıcıdırlar, gerçek dünyadan farklı olası dünyaları temsil ederler ve dünyayı belirli yönlerde değiştirecek projelerle ilgilidir (Fairclough, 2003: 124). Dünyanın tamamı ya da bir kısmında iktidar ve egemenlik alanı oluşturmak veya dönüştürmek amacıyla hazırlanan bu tip projeler söylem aracılığıyla örgütlenir ve kurumsallaştırılır. Bu süreçte baskı grupları ya da örgütsel yapının bazı üyeleri planlama, karar verme ve kontrol açısından özel bir role sahiptir (Van Dijk, 1993: 255). 
$\mathrm{Bu}$ çalışmada yeni kapitalist küreselleşmenin siyasi projesi olan neoliberalizmin $\mathrm{MB}$ bağımsızlığına yönelik taleplerini baskı grupları aracılığıyla nası yaygınlaştırmaya çalıştığı, Türkiye bağlamında TÜsiAD’ın söylemleri üzerinden gösterilmeye çalışılmaktadır. Güç ve iktidarın yerleştirilmesi ve korunmasında sosyal aktör ve baskı gruplarının söylemlerini belirleyici faktör olarak kabul eden Fairclough'un (2003; 2013) ESA modeli kullanılacaktır. Fairclough (2003: 4) bugünkü çağdaş toplumsal ve ekonomik düzeni tanımlamak için küreselleşme, geç modernite, bilgi toplumu, bilgi ekonomisi, yeni kapitalizm, tüketim kültürü gibi terimlerin kullanıldığını, kendisinin yeni kapitalizm terimini tercih ettiğini belirtmektedir. Ona göre yeni kapitalizm terimi sadece ekonomik konuları değil siyaset, eğitim, sanatsal üretim ve sosyal hayatın diğer alanlarını da kapsamaktadır. Neoliberalizm ise sınırlandırılmamış bir küresel kapitalizmin taleplerine uygun olarak sosyal ilişkilerin yeniden yapılandırılmasını kolaylaştıran politik bir projedir. Kapitalizmin yeni ruhu olan bu yeni biçimi çözümlemek için en kullanışlı yöntemlerden biri de ESA'dır (Fairclough, 2002:163; 2003: 123; 2005: 23). Bu nedenle çalışmada Fairclough'un ESA modeli tercih edilmiştir.

\subsection{TÜsiAD}

TÜSiAD (Türkiye Sanayici ve İş Adamları Derneği), 2 Nisan 1971 yılında, Türkiye'nin önde gelen 12 iş adamı tarafından kurulmuştur. Kuruluş amacı meslek, bilim ve iş adamlarının bilgi, tecrübe ve faaliyetlerini bütünleştirerek Türkiye'nin demokratik ve planlı kalkınmasına ve Batı uygarlık seviyesine ulaşmasına yardımcı olmak şeklinde belirtilmiştir. Ayrıca serbest teşebbüs fikrinin savunulması ve yaygınlaştırılması bir diğer temel amaç olarak belirlenmiştir. Demokrasi, insan hakları, girişim, inanç ve düşünce hürriyeti gibi evrensel değerlere bağlı kalınacağı ifade edilmiştir (Koyuncu, 2006: 128; Güzelsarı ve Aydın, 2010: 48-50; Emini, 2013: 49; Ercan ve Ercan, 2015: 398). TÜsiAD üyeliği gönüllülük esaslı olup, merkezi İstanbul'da bulunmaktadır. Şubesi olmayıp, Ankara ve gelişmiş bazı Batılı ülkelerin başkentlerinde temsilcilik ve büroları bulunmaktadır. Üyelik başvurusunda bulunan adayların üyelikleri ekonomi, eğitim, iş etiği gibi farklı kriterler üzerinden değerlendirilerek neticelendirilmektedir. Kurulduğu 1971 yılından itibaren çeşitli ekonomik meselelerle ilgili raporlar hazırlamış ve yayınlamıştır. Ancak 1979 yılında dönemin hükümetini ekonomik ve siyasi istikrar konusunda uyaran ilanlarla dikkat çekmiştir (Koyuncu, 2006: 129; Güzelsarı ve Aydın, 2010: 50-52; Emini, 2013: 50-51; Ercan ve Ercan, 2015: 402; Gölbaşı, 2015: 236-237; Gölbaşı, 2016: 189).

TÜSIAD 1960-1980 arasında uygulanan ithal-ikameci içe kapalı ekonomik sistemin terk edilmesi ve dışa açık bir ekonominin benimsenmesi yönünde çaba sarf etmiş, döviz gelirlerini arttırmayı ve dünya ekonomisine uyumda 'yeni bir insan tipi' yaratmayı (Kazgan, 2009: 123) amaçlayan 24 Ocak kararlarını ve 12 Eylül darbesini desteklemiştir. Sadece ekonomik içerikli raporların yeterli olmadığını düşünerek 1980'den itibaren politik, sosyal ve ekonomik içerikli raporlar hazırlamaya başlamıştır (Koyuncu, 2006: 130; Güzelsarı ve Aydın, 2010: 55-56; Gölbaşı, 2015: 237). Giderek bir baskı grubuna dönüşen TÜSIAD (Koyuncu, 2006: 130; Ercan ve Ercan, 2015: 405) modern, laik, liberal, çoğulcu bir kimliğin temsilcisi olarak kendi politik ve sosyal projelerini topluma ve siyasete dayatmaya çalışmıştır (Güzelsarı ve Aydın, 2010: 58-59).

Türkiye'de 24 Ocak 1980 kararlarından sonra dünya ekonomisine yönelik ikinci eklemlenme politikası 1989 yılında uygulamaya konulan TL'nin konvertible hale getirildiği 32 Sayılı karardır. Sermaye hareketlerinin serbestleştirildiği bu kararla Türkiye finansal açıdan dünya ekonomisiyle bütünleşerek (Sönmez, 2009: 42), neoliberal uygulamalara uyum da bir aşamayı daha geçmiştir. Ancak sermaye hareketlerinin serbestleştirildiği bu dönemden sonra Türkiye'de hükümetler MB'nın politika etkinliğini zaafa uğratacak şekilde sermaye piyasalarından 
borçlanmayı tercih etmişlerdir. Kamu borçlanmasında artışlara neden olan bu tercih, enflasyondaki artışla birlikte ekonomide ciddi istikrarsızlıkların oluşmasına yol açtığı gibi, faiz oranlarını da yükseltmiştir (Boratav, 2007: 186). Diğer taraftan 90'lı yıllarda \%50'nin üzerinde enflasyon oranının neredeyse sabitlenmesi ve siyasal istikrasızlıklar Türkiye'yi yüksek borç ve yüksek enflasyon sarmalı içine sokmuştur. Ayrıca yüksek faiz oranları ile TL'nin değerlenmesi ithalat artışı nedeniyle cari açığın daha da artmasıyla sonuçlanmıştır. Büyümenin ve makroekonomik politikaların Türkiye'ye girecek sermayeye bağımlı kılınması, ülke içindeki tasarrufları, finansal hareketlere ve dünya finans piyasasındaki gelişmelere daha duyarlı hale getirmiştir. Makroekonomik yapıda oluşan bu yapısal sorunlar, Türkiye'nin yedi yıl içinde (1994, 1999, 2000 ve 2001) dört tane ekonomik krizle karşılaşmasına sebep olmuştur (Pamuk, 2004: 395; Yenal, 2003: 106; Yeldan, 2013: 37). Bunun sonucunda Türkiye farklı hükümetler, tek siyaset olarak tanımlanan dönemin içine girmiş (Boratav, 2009: 3) ve IMF gözetiminde zorlayıcı (coercive) ve normatif (normative) eşbiçimlenme (isomorphism) (McNamara, 2002: 64-65) sürecine dâhil edilmiştir. Bütün bu gelişmeler sonucunda kurumsal yapılardaki dönüşümle neoliberal döneme geçişi tamamlama anlamına gelen Güçlü Ekonomiye Geçiş Programı́nın (GEGP) alt yapısı da hazırlanmıştır.

Bu süreç içinde yaşanılan ekonomik krizler ve siyasal istikrarsızlıklara yönelik çözüm önerileri ve neoliberal yapıya uyuma yönelik politika tercihleri TÜsiAD tarafından dile getirilmiştir. TÜSIAD 1990'lı yıllar itibariyle $A B$ üyelik süreci ve batı ile entegrasyona odaklanmış, Batı demokrasisi standartları üzerinden ekonomik ve siyasi liberalleşmenin başarılması için çaba göstermiştir. Kendisini sadece ekonomi çerçevesinde iş dünyasının sorunlarını tartışan ve öneriler sunan bir iş derneği olarak değil sosyal ve siyasal alanda bir baskı grubu olarak konumlandırmaktadır (Koyuncu, 2006: 131-133; Güzelsarı ve Aydın, 2010: 60-61). Bu doğrultuda $\mathrm{MB}$ bağımsızlığı gibi konular hakkında kamuoyunu yönlendirerek neoliberal politikaların Türkiye'de tanınması ve benimsenmesini hedeflemiş (Gölbaşı, 2016: 189) ve kurumsal düzenlemelerin yapılmasını raporlarında tavsiye etmiştir. Böylelikle politik ve ekonomik tartışmaların başat aktörü haline gelerek hedeflediği liberal toplumsal projenin kurucu söylemlerini merkeze taşıyan bir rol üstlenmiştir (Güzelsarı ve Aydın, 2010: 47).

Üyelerinin ekonomi içindeki payları düşünüldügünde TÜSIAD oldukça önemli bir aktördür. Yaklaşık 4500 şirketi temsil etmektedir ve bu şirketler kamu dışı milli gelirin yarısını (\%50) oluşturmakta, dış ticaretin \%85'ini (enerji ithalatı hariç) gerçekleştirmekte, kayıtlı istihdamın \%50'sini (kamu ve tarım hariç) sağlamakta ve kurumlar vergisinin \%80'ini ödemektedir (https://tusiad.org/tr/tusiad/hakkinda, erişim tarihi: 28/01/2021). TÜSiAD görüşlerini kamuoyuna raporlar, dergi gibi süreli yayınlar, çeşitli platformlardaki konuşmalar, yazılı ve görsel basına mülakatlar, gazetelere ilanlar aracılığıyla sunmaktadır (Emini, 2013: 50-52; Gölbaşı, 2016: 195; Güzelsarı ve Aydın, 2010: 53-54; Koyuncu, 2006: 132-133). Bu çalışmada sadece raporlar analize dahil edilmiştir. Kurulduğu 1971 yılından 2021 yılına kadar çeşitli konularda toplamda 450'den fazla rapor yayınlamıştır (http://tusiad.org/45-yil/, erişim tarihi: 28/01/2021). Türkiye ekonomisinde liberal dönüşüm 24 Ocak 1980 kararlarıyla başladığı ve MB'nın 2001 krizi sonrası bağımsızlığı güçlendirildiği için 1980-2000 yılları arası yayınlanan raporlar seçilmiştir.

\subsection{Analiz Yöntemi}

Fairclough'a (2003: 3) göre ESA modeliyle metinler sadece dilbilimsel açıdan değil söylemin düzeni olarak adlandırılan dilin sosyal yapısı dikkate alınarak analiz edilmelidir. Söylem, belirli bir perspektiften sosyal hayatın bazı alanlarının temsili oldukları için diğer bazı alan ya da 
metinlere atıfta bulunulabilir ve bu durum söylemin çok perspektifli okunması gerektiğini gösterir. Mesela bir söylem ya da ifade neoliberal kavramıyla eşleştirilebilir ve bu siyasi alanda belirli bir perspektifi etiketlemenin bir yoludur (Fairclough, 2013: 289-290). Fairclough'un (2001; 2003; 2013) ESA modeli üç aşamadan oluşmaktadır.

1. aşama (metin - söylem); metnin tanımlanması aşamasıdır. Söylem metni seçilen kelimeler, semantik ilişkiler, dilbilgisi ve metnin yapısı açısından incelenir. Burada doğrudan ifade edilmeyen örtük anlam ve niyet açığa çıkarılmaya çalışılır. Metni üretenin kendini nasıl konumlandırdığı ve ideolojik duruşu ortaya çıkarılır.

2. aşama (metinlerarasılık - söylemin düzeni); metnin yorumlanması aşamasıdır. Söylem metni yansıttığı ilişkiler açısından incelenir. Metindeki söylem başka hangi aktörlerin söylemleriyle örtüşmekte ya da benzeşmektedir, hangi aktörlerle iş birliği yapılmakta, hangileri dışlanmakta ve eleştirilmekte ortaya konulmaya çalışılır. Metinlerarasııık olarak adlandırılan bu durum, metnin diğer metinlerle ilişkisi ve hangi metinlere nasıl atıf yapıldığını göstermeye çalışır.

3. aşama (bağlam - sosyal yapı); metnin açıklanması aşamasıdır. Söylem metni üretildiği sosyal, kültürel, tarihsel, ekonomik ve politik bağlam açısından incelenir. Metne asıl anlamını veren üretildiği bağlamdır ve metnin anlaşılması sosyal bağlama göre değişmektedir. Bu nedenle sosyal bağlam dikkate alınmadan metnin doğru analiz edilmesi ve anlaşılması oldukça zordur.

\subsection{Analiz Materyali}

Metin 1. (M1) "Piyasa ekonomilerinde Merkez Bankaları hükümetlerin ekonomi politikalarını yürütmelerinde pasif değildirler. Merkez Bankalarının dünyada ve kendi ülkelerindeki ekonomik gelişmeleri takip ederek, ülkenin orta ve uzun vadeli çıkarlarına uygun olacak para politikaları tercihlerini ve hedeflerini saptamaları şarttır. Bu amaçları gerçekleştirebilmesi için Merkez Banka'sının tüm siyasi müdahalelerden uzak, özerk bir yapıya kavuşturulması gerekir" (TÜsiAD, 1990-Ocak: 9).

Metin 2. (M2) "Merkez Bankası hükümetin ekonomik ve mali politikasına uyumlu bir para politikası uygulayacak biçimde bağımsız bir yapıya kavuşturulmalıdır” (TÜsiAD, 1992-Ocak: 7).

Metin 3. (M3) “Belki de örgütlerin kurulmasından daha da önemli bir eğilim, Merkez Bankası gibi geleneksel bürokrasinin temel kurumlarının üst düzey yönetici kadrolarının değiştirilmesi ve böylelikle söz konusu kurumların yukarıdan başlatılan reform sürecinin içine itilmesidir. Genç ve genelde Amerika Birleşik Devletleri'nde lisansüstü eğitim görmüş ve serbest piyasa modelinin mantığına inanmış bir seçkin teknokrat grubu, kilit kurumların başına getirilmiştir. Bu tepeden başlatılan yeniden yapılanma süreci bazı kurumları köklü bir biçimde etkilemiştir. Merkez Bankası bu toptan köklü değişim sürecinin en belirgin örneğini oluşturmaktadır. Çok kısa bir süre içinde, Merkez Bankası modern bir banka konumuna dönüşmüş ve özerk bir kurum olma doğrultusunda önemli mesafe kaydetmiştir. Merkez Bankası bünyesinde giderek yaygınlaşan özerk yapının önemli bir boyutu atamaların giderek kurum içinde ve siyasal baskılardan bağımsız bir şekilde gerçekleşmesidir" (TÜSiAD, 1992-Nisan: 85).

Metin 4. (M4) "Kamu açıklarının enflasyonist etkisi, Merkez Bankasının bağımsız hareket edememesi nedeniyle daha da artmaktadır. Merkez Bankasının göreceli olarak bağımsız hareket edebildiği ülkelerde enflasyon kontrol altında tutulabilmektedir. Parasal istikrarın siyasal ve ekonomik istikrar sağlamadaki gerekliliği düşünüldüğünde Merkez Bankası'nın 
parasal istikrarı sağlama açısından bağımsızlığının önemi daha da artmaktadır" (TÜSiAD, 1992Kasım: 40).

Metin 5. (M5) "Gelişmiş ülkelerde siyasal gelişmelerden doğrudan etkilenmeyen Merkez Bankaları, bağımsız kimlikleriyle ekonomide güven ortamı oluşturarak, para politikasının başarıya ulaşmasında ön koşulu yerine getirebilmektedir. Ülkemizde ise son yıllarda yaşanan siyasal ve ekonomik çalkantılardan, Merkez Bankası (TCMB) olumsuz yönde etkilenmiştir. 1993 yılının ikinci yarısından itibaren geçen üç yılı biraz aşkın sürede, bu kuruluş dört ayrı başkan yönetiminde çalışmıştır. Bu duruma bir de para ikamesi ile kamu mali yapısında giderek ağırlaşan dengesizliklerin baskısı eklenince, para politikasının etkinliği azalmakta, Merkez Bankası ana görevi olan fiyat istikrarını sağlayacak öncelikli politikaları uygulayamamaktadır. 1996 yılında da özellikle yılın ilk yarısında yaşanan siyasal kargaşaya ve belirsizliğe bağlı olarak TCMB ana görevini yerine getirecek politikalar için gerekli ortamı ve gücü bulamamıştır" (TÜSIAD, 1997-Ocak: 43).

\section{Bulgular}

\subsection{Metnin Söylem Analizi}

M1, M2, M4 ve M5'te MB'lerin "bağımsız özerk yapıda" olmaları gerektiği belirtilirken, M1 ve M5'te bunun gerekçesi olarak "piyasa ekonomileri" (M1) ve "gelişmiş ülkelerdeki" (M5) genel durum gösterilmektedir. Özerk olmama; pasiflikle (M1), uygun para politikası tercih ve hedeflerini saptayamamakla (M1), siyasi müdahaleye açık olmakla (M1-M3-M5), ekonomide güven ortamı oluşturamamakla (M5), siyasal ve ekonomik çalkantılardan etkilenmekle (M5), sürekli başkanın değişmesiyle (M5), kamu mali yapısının baskısına maruz kalmakla (M5), enflasyonun artmasıyla (M5), kamu açıklarının enflasyonist etkiye maruz kalmasıyla (M4), parasal istikrarın sağlanamamasıyla (M4) ilişkilendirilmektedir. Gelişmiş ülke ve piyasa ekonomisi kavramları bir arada Batılı kapitalist ülkeleri işaret etmektedir. Günümüz yeni kapitalizminin (Fairclough, 2002: 163) kendine özgü kavramları ve bu kavramların herkesçe bilinen anlamları vardır (Mayr, 2015: 767). Kapitalizmin yeniden yapılandırılmasında dil ve kavramlar ekonomik dönüşümü kontrol etmek ve şekillendirmek için bilinçli müdahalenin aracı olarak kullanılmaktadır (Fairclough, 2002: 164). ESA küresel kapitalizmin neoliberal politik ve kurumsal söylemlerine ve kavramlarına odaklanmayı sağlayarak, sosyal ve ekonomik değişim sürecinin anlaşılmasına yardımcı olmaktadır (Mayr, 2015: 767).

Sınırlandırılmamış bir küresel kapitalizmin taleplerine uygun olarak sosyal ilişkilerin yeniden yapılandırılmasını ve yeniden ölçeklendirilmesini kolaylaştırmak için siyasi bir proje olarak tasarlanan "neoliberalizm" muhafazakâr, liberal, sosyal demokrat fark etmeksizin çoğu hükümet tarafından benimsenmiştir. Ekonomik yenilenme ve küresel ekonomiye entegrasyonun en iyi yolu olarak neoliberal politikalar gösterilmiş ve piyasa mekanizması mitselleştirilerek refah devletlerinin insanlara sağladığı koruma azaltılmıştır (Fairclough, 2013: 281). Piyasa ekonomileri (M1), gelişmiş ülkeler (M5), fiyat istikrarı (M5), parasal istikrar (M4) ve kamu mali yapısı (M5) vurguları üzerinden $\mathrm{MB}^{\prime}$ nin özerkliği savunulurken piyasa mekanizmasının mitselleştirilmesine benzer bir ilişkilendirme yapılmaktadır. Para politikasının başarıya ulaşmasının (M5), parasal istikrarın (M4) ve enflasyonun kontrol altına alınmasının (M4) ön koşulu olarak MB'nin bağımsızlığı gösterilmekte, olmazsa bunların başarılamayacağı izlenimi uyandırılmakta ve tartışılamayacak en iyi doğru yol olarak sunulmaktadır. Kamu mali yapısının MB üzerindeki baskısının artmasının para politikasının etkinliğini azalttığı ve $\mathrm{MB}^{\prime}$ nin ana görevi olan fiyat istikrarını sağlayacak öncelikli politikaları uygulayamadığı (M5) şeklindeki 
ifadeler Keynesçi sosyal (refah) devlet anlayışının değil Washington Uzlaşısının neoliberal piyasa ilkelerinin (Fairclough 2003: 128; 2005: 26) öncelendiğini göstermektedir.

Sosyal devlet anlayışı gereği MB'ler parasal genişleme ya da doğrudan kamu finansmanı aracılığıyla satın alma gücünü etkilemekte ve bu da fiyat istikrarı üzerinde bozucu etki meydana getirebilmektedir. Fiyat istikrarının öncelikli hedef haline getirilmesi sosyal devleti arka plana iten bir yaklaşımı ifade etmektedir. Bu da MB bağımsızlığına yönelik eleştiri ve taleplerin MB bağımsızlığı ile para politikalarının iyileştirilmesi arasında doğrudan bir ilişki kurmak yerine genelgeçer doğru kabul edilen neoliberal düşüncenin varsayımlarına dayandığını göstermektedir. Nası ki varsayımsal olarak rekabet ve verimlilik için uluslararası piyasalara uygun düzenleme ve reformlar gerekli görülüyorsa, aynı şekilde varsayımsal olarak etkin para politikası için fiyat istikrarının öncelenmesi gerektiği öne sürülmektedir. Bir diğer ifadeyle uluslararası piyasalara uyum sağlamadan verimlilik ve rekabet olamayacağı varsayımına benzer şekilde fiyat istikrarı öncelenmeden etkin para politikası uygulanamayacağı varsayımından hareket edilmektedir. Rekabet ve verimlilik gibi etkin para politikası ve fiyat istikrarı da neoliberal ekonomik değişimin söylem ve kavramlarıdır (Fairclough, 2003: 128). Metinlerde kullanılan kavramlar, kavramların kullanılma biçimleri, anlam ilişkileri ve metinlerin yapısı TÜSIAD’ın kendini neoliberal projenin bir temsilcisi olarak konumlandırdığını ve bu projeye uygun uygulamaların benimsetilmesi ve yaygınlaştırılması yönünde bir duruş sergilediğini göstermektedir.

\subsection{Metnin Metinlerarası Analizi}

MB'lerin özerkliğine (M1, M2, M4, M5) yönelik öneri ve talepler sadece para politikalarının iyileştirilmesi çerçevesinde ele alınmamasını gerektirecek ölçüde farklı unsurları barındırmaktadır. Bu öneri ve taleplerin arka planında çok daha kapsamlı ekonomik, politik, sosyal ve ideolojik örtülü gerekçeler söz konusudur. Yeni kapitalizmin önündeki engelleri kaldırmaya yönelik tasarlanan neoliberal siyasi projenin yönetişim, esneklik, küreselleşme, özelleştirme gibi kavramları öne çıkaran kendine özgü bir propaganda dili vardır. Bu kapitalist neoliberal dönüşümü anlamak için kullanılan kelime ya da kavramların listesini bilmek yeterli olmamakta, metinlerin ve metinler arası etkileşimlerin ortaya çıkarılması gerekmektedir. Bu dönüşümün önündeki engelleri kaldırmak için baskı gruplarınca girişilen hükümet politikalarını etkileme ve kendi arzularını gerçekler olarak yansıtma stratejileri de dikkate alınmalıdır (Fairclough, 2013: 282). Bu doğrultuda MB'nin özerkliği ve fiyat istikrarı kavramları, geniş düzlemdeki politik ve ekonomik söylemlerle ilişkisi ve etkileşimi açısından değerlendirilmelidir. Analiz edilen metnin metin ağlarında nerede konumlandığı önemlidir, geçmişe ya da geleceğe dönük olabilir, onu yönlendiren ona yönelik olan, temsil eden ya da çağrıştıran metinlerle ilişki içinde olabilir (Fairclough, 2013: 291-292). Metinlerde MB'nin “ülkenin orta ve uzun vadeli çıkarlarına uygun olacak para politikaları tercihlerini ve hedeflerini saptamaları şarttır" (M1) denilmekte ve ardından "bu amaçları gerçekleştirebilmesi için MB'nin tüm siyasi müdahalelerden uzak, özerk bir yapıya kavuşturulması gerekir" (M1) ifadesi kullanılmaktadır. Yani siyasi müdahalenin ülkenin çıkarlarına uygun para politikası belirlenmesinin önünde bir engel olduğu varsayımından hareket edilmekte ancak ülkenin çıkarının nasıl tanımlandığı belirtilmemektedir. Sosyal devlet anlayışını destekleyici politikaların terk edilmesi sermaye gruplarının ya da iş dünyasının çıkarına olabilir ancak toplumun geniş kesimlerinin çıkarına uygun olduğu tartışmalıdır. Burada kendi arzularını gerçekler olarak yansıtma stratejisi açık şekilde görülmektedir. MB'nın bağımsız hareket edememesinin enflasyonu kontrol altında tutulabilmesini engellediği ve bunun da kamu açıklarında enflasyonist etkiye neden olduğu 
(M4) ifade edilmektedir. Ardından enflasyonu kontrol altına alacak parasal istikrarın ekonomik ve siyasal istikrar üzerindeki etkisine gönderme yapılmaktadır (M4). Dolayısıyla ülkenin siyasal ve ekonomik istikrarı MB'nın bağımsızlığına bağlanmakta ya da onunla ilişkilendirilmektedir. Böylelikle $M B$ bağımsızlığı gibi kurumsal bir uygulama ülkenin siyasi ve ekonomik istikrarı üzerinden meşrulaştırılmaya ve benimsetilmeye çalışılmaktadır.

"Piyasa ekonomileri" (M1), "gelişmiş ülkeler" (M5), "fiyat istikrarı öncelikli politikalar" (M5), "parasal istikrarı sağlama" (M4) ve "siyasi müdahalelerden uzak" (M1-M5) ifadeleri metni üretenin kimlerle ilişki ve iş birliği içinde olduğu ve aynı zamanda neyi ve kimleri dışladığı, hangi metin ve söylemlere atıf yapıldığı konusunda bir fikir vermektedir. Söylem sosyal dünyanın inanç ve duygu, zihin dünyasının düşünce, maddi dünyanın yapı ve ilişki gibi boyutlarını temsil ettiği için farklı perspektifler farklı söylemlere sahiptir ve dolayısıyla farklı söylemler de farklı perspektifleri yansıtır (Fairclough, 2003: 124). Mesela siyasi müdahalelerden uzak özerk kurumlar söylemi neoliberal perspektifi yansıtmaktadır. Topluma hesap vermekle yükümlü seçilmiş siyasilerden bağımsız teknokrat özellikli kurumsal yapılar oluşturmak küresel neoliberal projenin önemli aşamalarından biridir. Bağımsız teknokrat terimi ile neoliberal söylem arasındaki ilişki şu ifadelerde daha açık görülebilmektedir: “... ABD’de lisansüstü eğitim görmüş ve serbest piyasa modelinin mantığına inanmış bir seçkin teknokrat grubu, kilit kurumların başına getirilmiştir... yapılanma süreci bazı kurumları köklü bir biçimde etkilemiştir. Merkez Bankası... en belirgin örneğini oluşturmaktadır... Merkez Bankası modern bir banka konumuna dönüşmüş ve özerk bir kurum olma doğrultusunda önemli mesafe kaydetmiştir" (M3). ABD'de eğitim görme, serbest piyasa modeli, modern bankacılık anlayışı gibi ifadeler neoliberal anlayışla ilişkilidir. Bunlara sahip olma seçkin teknokrat statüsü sağlamaktadır ve bu özellikteki teknokratlar MB'nı özerk bir yapıya kavuşturmaktadır. Farklı metinler gibi görünse de bu kavram ya da ifadelerin hepsi birbiriyle ilintili ve birbirini tamamlayıcıdır. Bağımsız teknokratların kontrol ettiği ve politika belirlediği gelişmiş ülkelerdeki gibi serbest piyasa işleyişi ve fiyat istikrarı öncelikli para politikaları gibi hedefler uluslararası şirketlerin ve finans kuruluşlarının istekleriyle uyumludur. Çünkü onlar devletin kamu yararı adına müdahale etmediği bir piyasa ve yönlendirmediği bir politika işleyişinin kendileri açısından daha elverişli bir ortam sunduğunu düşünmektedir. Küresel neoliberal proje bu taleplerini IMF, Dünya Bankası, Dünya Ticaret Örgütü ve OECD gibi uluslararası kuruluşlar aracılığıyla kabul ettirmeye ve yaygınlaştırmaya çalışmaktadır (Fairclough, 2013: 282-283).

Özgül ve yerel söylemler hariç, genel söylemler belirli şekillerde bir araya getirilen diğer söylemlerin kombinasyonları olarak görülebilir. Mevcut söylemleri belirli şekillerde bir araya getirerek yeni söylemler böyle ortaya çıkar (Fairclough, 2003: 126-127). Bu nedenle "piyasa ekonomileri" (M1), "gelişmiş ülkeler" (M5), "fiyat istikrarı öncelikli politikalar" (M5), "parasal istikrar" (M4) ve "siyasi müdahalelerden uzak" (M1-M5) gibi birbiriyle ilgisi ve ilişkisi yokmuş gibi görünen söylemleri, atıfta bulunulan üst bir soyutlama düzeyinde bir araya getirip daha ayrıntılı bakıldığında durum netleşmektedir (Fairclough, 2003: 126). Ifadelerin neoliberal projenin bütüncül söyleminin birer parçası olduğu ve birbirlerini anlamlı şekilde tamamladıkları görülmektedir. Metinlerin dokusunu oluşturan ilişkiler, diğer söylemlerle ilişkili söylemler oluşturmakta ve küresel ve ulusal düzeyde aynı terimlerle ifade edilebilmektedir. Bu durum neoliberal politik söylemin karakteristiğidir ve aynı zamanda önceki politik söylemleri yıkıcı bir özellik taşımaktadır (Fairclough, 2013: 290-291). MB'na siyasi müdahalenin (M1-M5), fiyat istikrarı öncelikli politika üretilmemesinin (M4-M5) ve geleneksel bürokrasinin (M5) eleştirilmesi ve ötekileştirilmesi bu karakteristikten kaynaklanmaktadır. 


\subsection{Metnin Bağlamsal Analizi}

"Ekonomide güven ortamı" (M5), "siyasal ve ekonomik çalkantılar" (M5), "üç yılda dört ayrı başkan" (M5), "kamu mali yapısında dengesizliklerin baskısı" (M5), "kamu açıklarının enflasyonist etkisi" (M4), "parasal istikrarın sağlanamaması" (M4), "siyasal kargaşa ve belirsizlik" (M5) ve "fiyat istikrarına yönelik politikalar için gerekli ortamı ve gücü bulamama" (M5) gibi ifadeler metnin hangi bağlamda üretildiğini göstermektedir. Metnin bağlamsal analizi hem metnin üretildiği bağlamsal şartları analiz etmeyi hem de metindeki söylemin yeniden nasıl bağlamsallaştırıldığını çözümlemeyi içermektedir. Öncelikle metnin üretildiği bağlamsal şartların olumsuzluğu ön plana çıkarılmakta ve yeni bir çıkış yoluna ihtiyaç duyulduğu vurgulanmaktadır. Çünkü politik ve ekonomik iktidar ya da hegemonya baskı yoluyla değil üyeler ve kamuoyunun söylem yoluyla ikna edilmesiyle elde edilir ve korunur. Toplumdaki baskı gruplarının kendi politik, ekonomik ve kültürel değerlerini alt gruplara kabul ettirmede kullandıkları söylem mekanizmaları ne kadar meşru ve sağduyulu görünürse kabul ettirme ihtimalleri o kadar yüksektir (Mayr, 2015: 758). Bu nedenle eğer bir dönüşüm arzu ediliyorsa önce mevcut sistemin gözden düşürülmesi ve buna yönelik yıkıcı bir söylemin inşa edilmesi gerekmektedir. Yeniden bağlamsallaştırma ise sömürgeleştiren ve kendine mal eden bir diyalektik olarak görülmelidir. Örneğin, ekonomik ile politik alan, küresel ile ulusal ölçek arasındaki yeniden bağlamsallaştırma ilişkilerine atıfta bulunulabilir. Yeni ekonomik düzen veya ekonomik küreselleşme gibi ifadeler Dünya bankası, IMF ve OECD gibi uluslararası örgütlerin metinlerine bir atıftır ve küresel ölçek üzerinden bağlamsallaştırma yapılmaya çalışıldığını göstermektedir (Fairclough, 2013: 293).

Metnin üretildiği bağlamsal şartlar; siyasal ortamın kargaşa ve çalkantı içinde olduğu, bunun MB yönetiminde istikrarın yakalanmasını ve ekonomik güven ortamının oluşmasını engellediği, kamu mali yönetiminin neden olduğu baskı ile birlikte siyasetin $\mathrm{MB}^{\prime}$ na müdahale etmesi sonucu parasal istikrara ve fiyat istikrarına yönelik politikalar uygulayacak ortam ve gücün kalmadığı bir ortam şeklinde resmedilmektedir. Siyasal ve ekonomik istikrar parasal istikrara, parasal istikrar da MB'nın bağımsızığına bağlanarak (M4), en iyi çıkış yolunun MB'nın bağımsızlığı olduğu şeklinde bir kanaat oluşturulmaya çalışılmaktadır. Serbest piyasa modeli mantığına inanmış seçkin teknokratlar MB'nı bağımsız yapıya kavuşturarak (M3) parasal istikrarı sağlayacaklar ve dolayısıyla ekonomik ve siyasi istikrara önemli katkıda bulunacaklardır izlenimi uyandırılmak istenmektedir. Neoliberal düşüncede yönetim sadece hükümetlerin işi olarak görülmemekte ve yönetişim gibi kavramlar öne çıkarılmaktadır. Bu çerçevede Dünya Bankası ve IMF gibi Washington Konsensüsünü dayatmada merkezi olan uluslararası ajanslara ve şeffaflık, hesap verebilirlik gibi uluslararası ilkelere atıf yapılmaktadır (Fairclough, 2003: 128; 2005: 25). MB'nın bağımsız özerk yapıda olmasının istenmesinin de asıl sebebi yönetim hakkının hükümette olmaması ve yönetişim mekanizması sayesinde hükümet dışı güçlü aktörlerin etkisine açık hale gelmesidir. Böylelikle ülke içi baskı grupları ve neoliberal küresel düzenin diğer aktörleri MB politikaları üzerinde yönlendirici ve belirleyici düzeyde daha etkili olabileceklerdir.

Söylemin yeniden bağlamsallaştırılması, söylem öğeleri arasında yeni ağ ilişkileri kurulmasıdır. Mesela yönetişim, kurum kültürü, devletin küçülmesi gibi yeni yönetim dilinin kavramlarının üniversiteler ve kamu kurumlarına girmesi ve o kurumlarca kendilerine mal edilmesidir. IMF ve Dünya Bankası gibi kuruluşlar veya üniversiteler aracılığıyla küresel olarak yayılan söylemler küresel, bölgesel, ulusal ve yerel ağlar sayesinde dünyanın birçok ülkesinde dönüşümü yönlendirmektedir (Fairclough, 2013: 282-283). ABD’de lisansüstü eğitim görmüş serbest piyasa mantığına inanan seçkin teknokratların $M^{\prime} B^{\prime} ı$ özerkliğe kavuşturmadaki rolüne 
(M5) yapılan atıf bunun bir ifadesidir. Yeni kapitalizmin dönüşümlerinin küreselleştirici karakteri, küreselden yerele daha akışkan davranış biçimlerini mümkün kılan ve düzenleyen yeniden bağlamsallaştırmaları içermektedir (Fairclough, 2013: 293). Bu nedenle gelişmiş ülkeler (M5), piyasa ekonomileri (M1), MB'nin bağımsız hareket edebildiği ülkeler (M4), ABD (M3) gibi küresel ölçeklere göndermede bulunulur. Yerel ile küresel arasında meşrulaştırıcı ve normalleştirici bağ bu şekilde kurulur ve kurumsal bilinç dönüştürülmeye çalışılır. Yeniden bağlamsallaştırma, toplumsal yaşamın farklı alanları arasındaki ilişkilerde dramatik değişimlerle ilgilidir ve en önemlisi de ekonomik alan ile siyaset, eğitim ve kültür gibi diğer alanlar arasında, sömürgeleştirme ilişkisi kurulması gerekir. Bu dönüşümde önce okullar ve üniversiteler gibi kurumların zihinleri yeniden inşa edilmektedir. Üniversitelerde akademisyenler ve batılı kapitalist ülkelerden tercüme ders kaynaklarıyla girişimci, otonom, özerk, yönetişim gibi neoliberal kurumsal söylemler yaygınlaştırılmaya ve küresel iş kültürü yaratılmaya çalışılmaktadır (Mayr, 2015: 767). ABD’de lisansüstü eğitim görmüş serbest piyasa mantığına inanan seçkin teknokratların (M3) vurgulanması ve olumlanması bu açıdan okunmalıdır.

Küresel ekonomi veya kapitalist küreselleşme olarak adlandırılan olgu bazı perspektiflerde ekonomik değişime egemen olan ulus ötesi şirketlerle ilişkilendirilmekte iken diğer bazı perspektiflerde bu şirketler görmezden gelinmekte ve küresel ekonomik değişim sosyal aracıları olmayan bir süreç olarak tanımlanmaktadır (Fairclough, 2003: 127). Türkiye'de de küreselleşme, batılılaşma, serbest piyasa modelini benimseme, özelleştirme, devletin küçülmesi gibi düşüncelerin sosyal aracı aktörleri unutulmakta ya da göz ardı edilmekte bu süreçler kendiliğinden doğal gelişmelermiş gibi yansıtılmaktadır. Oysaki her biri neoliberal ideolojinin ve yeni kapitalist hegemonyanın birer aşaması ve parçasıdır. Başta TÜsiAD olmak üzere meslek örgütleri, üniversiteler, sivil toplum örgütleri gibi aktörler aracılığıyla bu yeni anlayış ve düzen meşrulaştırılmaya, normalleştirilmeye, yaygınlaştırılmaya ve kurumsallaştırılmaya çalışılmaktadır. Kontrol ettiği basın ve medya gücü sayesinde diğer görüşlere alan bırakmayan ve tek çıkış yolunun neoliberal politikalar olduğu şeklinde tavsiyeler ya da önerilerde bulunan tek sesli bir düşünme bloğu meydana getirilmiştir. Bu nedenle yeni kapitalist güç yapılarının söylemlerinin görünürdeki özgürlükçü ve konsensüse dayalı dilinin özünde daha hegemonik bir niyete ve bilince dayandığı söylenebilir (Mayr, 2015: 768; Fairclough, 2005: 26). Günümüzde neoliberal düşünce ve iddiaların tek baskın söylem olarak diğer alternatifleri bastırması, çeşitli söylem stratejileri ile siyaset, iş dünyası ve toplum üzerinde etkili olması kendiliğinden gelişen doğal bir süreç olarak değerlendirilmemeli, aksine küresel ve yerel aracıları ile meşrulaştırılmaya, kabul ettirilmeye ve benimsetilmeye çalışılan planlı ve hedefleri belirli olan küresel bir proje olarak ele alınmalıdır.

\section{Sonuç}

Küreselleşme ve onun ideolojisi olan neoliberalizm, piyasanın işleyişinin tam anlamıyla tesis edilebilmesi için sadece ekonomik yapının değil devletlerin, siyasetin ve toplumların da dönüşümünü gerekli görmektedir. Bu sistem içinde devletler bazı temel işlevlerini özerk kurumlara terk etmeleri konusunda zorlanmaktadır. Uluslararası sistem içinde yer alması hem uluslararası hem de iç aktörlere karşı belirsizliği minimuma indirme sorumluluğu yüklemektedir. Bu durum daha önceden siyaset yoluyla elde edilen meşruiyetin yerini kurumsal dönüşümler yoluyla piyasadan sağlanan meşruiyetin alması anlamına gelmektedir. Bu meşruiyetin piyasada güvenin tesisini ve makroekonomi politikalarında istikrarı sağlanması beklenmektedir. Kurumsal dönüşüm ise para politikasında siyasal aktörlerin etkisini minimuma indiren $M^{\prime} B^{\prime} ı n$ bağımsız yapıya kavuşturulmasıdır. Bu dönüşümün gerçekleştirilmesi için küresel kurumların ve 
yerel aktörlerin siyaset ve toplum üzerinde baskı oluşturdukları görülmektedir. Yerel baskı grupları içerisinde en etkili olan ise TÜSiAD'dır. TÜSIAD, kurulduğu dönemden itibaren hükümetlere siyasal ve ekonomik önerilerde bulunmuş, dünya sistemine uyum sağlamak için bir fırsat olarak gördüğü 24 Ocak 1980 kararlarını desteklemiştir. Dünya ekonomik sisteminde meydana gelen değişmeleri sıkı bir şekilde takip eden TÜSiAD, 90'lı yıllarda da aynı misyonu devam ettirip, Washington Uzlaşısı sonrası tamamen açığa çıkan neoliberal politikaların Türkiye'ye yerleştirilmesinin takipçisi olmuştur. Böylece Türkiye'de hükümetlerin uluslararası sistem içinde siyaset yapmalarını ve küresel sistem ile birlikte hareket etmelerini teşvik etmiştir.

Analiz edilen raporlardaki metinlerden de anlaşılacağı üzere kurumsal dönüşüm sürecinin en önemli ayağını oluşturan $M B$ bağımsızlığına, hükümetlerden çok önce vurgu yapmıştır. TCMB, 2001 yılında uygulamaya konulan Güçlü Ekonomiye Geçiş Programı ile bağımsız olmasına karşılık, TÜSiAD 90'lı yılların başından itibaren, fiyat istikrarının tesisi ve kamu bütçesinde disiplinin sağlanması açısından MB'nin bağımsızlığını önermiştir. Güçlü bir baskı grubu olarak dünya sistemine entegre olmanın öncüsü rolünü oynamış, neoliberal dönüşümün temsilcisi ve sözcüsü olmuştur. Ekonomik ve siyasal istikrarsızlıklardan etkilenmeyen teknokratların yönettiği bağımsız MB aracılığıyla uluslararası piyasalarda rekabet dezavantajının önleneceğini ve sermaye çıkışının engelleneceğini öne sürerek siyasi, ekonomik ve toplumsal aktörleri ikna etmeye çalışmış ve toplumun bu dönüşüm sürecine hazır hale gelmesi için yoğun çaba göstermiştir. Sonuç olarak Türkiye'de MB'nın bağımsız bir kurum olmasında baskı grubu olarak TÜSiAD'ın etkin bir rol oynadığı söylenebilir. 


\section{Kaynakça}

Acemoğlu, D. ve Robinson, J. A. (2013). Ulusların Düşüşü: Güç, Zenginlik ve Yoksulluğun Kaynakları. (Çev. F. R. Velioğlu), İstanbul: Doğan Kitap.

Akerlof, G. ve Shiller, R. J. (2010). Hayvansal Güdüler, İnsan Psikolojisi Ekonomiyi Nasıl Yönlendirir ve Küresel Kapitalizm için Niçin Önemlidir? (Çev. N. Domaniç ve L. Konyer), İstanbul: Scala Yayıncılık.

Alesina, A. (1988). Macroeconomics and Politics, (Ed. S. Fischer), NBER Macroeconomics Annual Vol. 3, MIT Press: 13-62.

Alesina, A. F. ve Stella, A. (2010). The Politics of Monetary Policy. NBER Working Paper No: 15856, Cambridge.

Andrews, D. M. (1994). "Capital Mobility and State Autonomy: Toward a Structural Theory of International Monetary Relations", International Studies Quarterly, Vol.38, No. 2: 193-218.

Arestis, P. ve Sawyer, M. (2003). Inflation Targeting: A Critical Appraisal. The Levy Economic Institute of Bard College Working Paper. No: 388 September.

Arrighi , G. (1990). "The Three Hegemonies of Capitalism”, Review (Fernand Braudel Center), Vol.13, No. 3: 365408.

Arrighi, G. (2000). Uzun Yirminci Yüzyıl: Para, Güç ve Çağımızın Kökenleri, (Çev. R. Boztemur) Ankara: İmge Kitabevi.

Baldwin, R. E. ve Philip, M. (1999). Two Waves of Globalization: Superficial Similarities, Fundamental Differences. NBER Working Paper Series No: w9604 January.

Barro, R. J. ve Gordon, D. B. (1983). "Rules, Discretion And Reputation in a Model of Monetary Policy", Journal of Monetary Economics, Vol. 12, No. 1: 101-121.

Bearce, D. H. (2003). "Societal Preferences, Partisan Agents, and Monetary Policy Outcomes", International Organization, Vol. 57, No. 2: 373-410.

Bernhard, W., Broz, J. L. ve Clark, W. R. (2002). "The Political Economy of Monetary Institutions", International Organization, Vol. 56, No. 4: 693-723.

Berument, H. ve Neyaptı, B. (1999). Türkiye Cumhuriyet Merkez Bankası Ne Kadar Bağımsız. İktisat, İşletme ve Finans Dergisi, C. 14, S. 165: 11-17.

Bhagwati, J. N. (2009). "Küreselleşme ve Uygun Yönetişim", (Çev., F. İsmihan), (Ed F. Şenses), Neoliberal Küreselleşme Ve Kalkınma Seçme Yazılar, İstanbul: İletişim Yayınları: 573-615.

Blancheton, B. (2016). "Central Bank Independence in a Historical Perspective. Myth, Lessons and a New Model", Economic Modelling, Vol. 52: 101-107.

Boratav, K. (2007). Türkiye İktisat Tarihi 1908-2005. Ankara: İmge Kitabevi.

Boratav, K. (2009). "Bir Çevrimin Yükselişi Aşamasında Türkiye Ekonomisi”, (Ed, N. Mütevellioğlu ve S. Sönmez), Küreselleşme, Kriz ve Türkiye'de Neoliberal Dönüşüm. İstanbul: İstanbul Bilgi Üniversitesi Yayınları:1-24.

Bordo, M. D., Eichengreen, B. ve Irwing, D. A. (1999). Is Globalization Today really Different than Globalization a Hundred Years ago?, NBER working paper series. No: w7195. June.

Broz, J. L. (2002). "Political System Transparency and Monetary Commitment Regimes”, International Organization, Vo.56, No. 4: 861-887.

Campbell, J. L. (1998). "Institutional Analysis and the Role of Ideas in Political Economy”, Theory and Society, Vol. 27, No. 3: 377-409.

Centeno, M. A. (1993). "The New Leviathan: The Dynamics And Limits of technocracy", Theory and Society, Vol. 22, No. 3: 307-335.

Cerny, P. G. (1994). "The Dynamics of Financial Globalization: Technology, Market Structure, and Policy Response", Policy Sciences, Vol. 27, No. 4: 319-342.

Chang, H.J. (2009). "Merdiveni Tekmelemek: Tarihi Bir Perspektif İçinde "İyi Politikalar" ve "İyi Kurumlar". (Çev, N. D. Güngör), (Ed. F. Şenses), Neoliberal Küreselleşme Ve Kalkınma Seçme Yazılar, İstanbul: İletişim Yayınları: 89-122.

Chang, H.J. ve Evans, P. (2009). "Ekonomik Değişimde Kurumların Rolü", (Çev., A. Ganioğlu), (Ed. F. Şenses), Neoliberal Küreselleşme ve Kalkınma Seçme Yazılar, İstanbul: İletişim Yayınları: 617-678.

Chari, V. V. ve Kehoe, P. (2006). "Modern Macroeconomics in Practice: How Theory is Shaping Policy?", The Journal of Economic Perspectives, Vol. 20, No. 4: 3-28.

Clark, G. (2013). Fukaralığa Veda: Dünyanın Kısa İktisadi Tarihi, (Çev. E. Demircioğlu) İstanbul: İstanbul Bilgi Üniversitesi Yayınları. 


\section{Eskişehir Osmangazi Üniversitesi İktisadi ve İdari Bilimler Fakültesi Dergisi}

Clark, W. R. (2002). "Partisan and Electoral Motivations and the Choice of Monetary Institutions under fully Capital Mobile", International Organization, Vol. 56, No.4: 725-749.

Cohen, B. J. (1998). The Geography of Money, London: Cornell University Press.

Cohen, B. J. (2008). “The Geopolitics of Currencies and the Future of International System”, (Ed. B. J. Cohen), Global Monetary Governance, London and New York: Routledge: 225-254.

Corden, M. (2003). "Monetary Integration: The Intellectual Pre-History", (Ed. M. Baimbridge ve P. Whyman), Economic and Monetary Union in Europe Theory, Evidence and Practice, Massachusetts: Edward Elgar Publishing: 1730.

Cox, R. W. (1992). “Global Perestroika”. Socialist Register, Vol. 28: 26-43.

Crowe, C. ve Meade, E. E. (2007). "The Evolution of Central Bank Governance around the World", Journal of Economic Perspectives, Vol. 21, No. 4: 69-90.

Crowe, C. ve Meade, E. E. (2008). "Central Bank Independence and Transparency: Evolution and Effectiveness", European Journal of Political Economy, Vol. 24: 763-777.

Cukierman, A. (1992). Central Bank Strategy, Credibility and Independence: Theory and Evidence, Cambridge: MIT Press.

Cuikerman, A. (1994). "Central Bank Independence and Monetary Control", The Economic Journal, Vol. 104, No. 427: $1437-1448$

Cukierman, A. (2008). "Central Bank Independence and Monetary Policymaking Institutions: Past, Present and Future", European Journal of Political Economy, Vol. 24: 722-736.

Cukierman, A. ve Webb, S. B. (1995). "Political Influence on the Central Bank: International Evidence”, The World Bank Economic Review, Vol. 9, No. 3: 397-423.

Cukierman, A., Webb, S. B. ve Neyapti, B. (1992)." Measuring the Independence of Central Banks and its Effects on Policy Outcomes", The World Bank Economic Review, Vol. 6, No. 3: 353-398.

Dardot, P. ve Laval, C. (2012). Dünyanın Yani Aklı Neoliberal Toplum Üzerine Deneme. (Çev., I. Ergüden) İstanbul: İstanbul Bilgi Üniversitesi Yayınları.

de Haan, J., Bodea, C., Hicks, R. ve Eijffinger, S. C. (2018). "Central Bank Independence before and after the Crisis", Comparative Economic Studies, Vol. 60: 183-202.

Dinçer, A. (2004). "Türkiye Cumhuriyet Merkez Bankası ile Avrupa Merkez Bankasının Bağımsızlık Yönünden Karşılaştırılması", İktisat, İşletme ve Finans Dergisi, C. 19, S. 220: 95-105.

Emini, F. T. (2013). "Sivil Toplum Kuruluşlarının Politika Belirleme Sürecindeki Rolü: TÜSiAD Örneği”, Dumlupınar Üniversitesi Sosyal Bilimler Dergisi, C. 36: 43-56.

Ercan, A. ve Ercan, B. (2015). "Türkiye'de Ekonomik Elit Davranışları ve Bir Ekonomik Seçkinler Örgütü Olarak TÜSIAD”, Uluslararası Sosyal Araştırmalar Dergisi, C. 8, S. 41: 397-406.

Evans, P. (1997). "The Eclipse of the State? Reflections on Stateness in an Era of Globalization", World Politics, Vol. 50, No. 1: 62-87.

Fairclough, N. (2001). "Critical Discourse Analysis as a Method in Social Scientific Research", (Ed. R. Wodak ve M. Meyer), Methods of Critical Discourse Analysis, London: Sage: 121-138.

Fairclough, N. (2002). “Language in New Capitalism”, DiscourseveSociety, Vol. 13, No. 2: 163-166.

Fairclough, N. (2003). Analyzing Discourse: Textual Analysis for Social Research, London: Routledge.

Fairclough, N. (2005). “Neoliberalism: A Discourse Analytical Perspective”, Polifonia, Vol. 10: 21-52.

Fairclough, N. (2013). Critical Discourse Analysis: The Critical Study of Language, New York: Routledge.

Finnemore, M., ve Sikkink, K. (1998). "International Norm Dynamics and Political Change", International Organization, Vol.52, No. 4: 887-917.

Friedman, M. (1963). Capitalism and Freedom. Chicago: University of Chicago Press.

Fukuyama, F. (1989). "The end of History?", The National Interest, Vol. 16: 3-18.

Fukuyama, F. (1999). Tarihin Sonu ve Son İnsan, (Çev., Z. Dicleli), İstanbul: Gün Yayıncılık.

Germain, R. (2009). "Financial ORDER and World Politics: Crisis, Change and Continuity", International Affairs, Vol. 85 , No. 4: 669-687.

Gilpin, R. (1975). “Three Models of the Future”, International Organization, Vol. 29, No. 1: 37-60. 
Gilpin, R. (2011). Uluslararası İlişkilerin Ekonomi Politiği, (Çev., M. Duran, S. Oktay, M. K. Ceyhan ve G. Polat), Ankara: Kripto.

Goodfriend, M. (2007). "How the World Achieved Consensus on Monetary Policy", Journal of Economic Perspectives, Vol. 21, No. 4: 47-68.

Goodman, J. B. (1991). The Politics of Central Bank Independence, Comparative Politics, 23(3), 329-349.

Gölbaşı, S. (2015). "Türk İş Sisteminin Piysasa Temelli Kurumsal Dönüşümünü Olanaklı Kılan Koşullar”, Süleyman Demirel Üniversitesi İktisadi ve İdari Bilimler Fakültesi Dergisi, C. 20, S. 2: 225-246.

Gölbaşı, Ş. (2016). "Değişimin Kuramlaştırılması: İş Derneklerinin Alanlarındaki Kurumsal Dönüşüme Müdahalesi”, Cumhuriyet Üniversitesi İktisadi ve İdari Bilimler Dergisi, C.17, S. 1: 187-207.

Grilli, V., Masciandaro, D. ve Tabellini, G. (1991). "Political and Monetary Institutions and Public Financial Policies in the Industrial Countries", Economic Policy, Vol. 6, No. 13: 341-392.

Güzelsarı, S. ve Aydın, S. (2010). “Türkiye'de Büyük Burjuvazinin Örgütlü Yükselişi: Siyasal ve Yönetsel Süreçlerin Biçimlenmesinde TÜSiAD”, Abant İzzet Baysal Üniversitesi Sosyal Bilimler Enstitüsü Dergisi, Vol.1, No. 20: 43-68.

Haggard, S. ve Kaufmann, R. R. (1995). The Political Economy of Transitions, Princeton: Princeton University Press.

Hall, P. A. ve Franzese, R. J. (1998). “Mixed Signals: Central Bank Independence, Coordinated Wage Bargaining, and European Monetary Union", International Organization, Vol. 52, C.3: 505-535.

Harvey, D. (2015). Neoliberalizmin Kısa Tarihi, (Çev. A. Onocak), İstanbul: Sel Yayıncılık.

Harvey, D. (2010). Postmodernliğin Durumu Kültürel Değişimin Kökenleri, (Çev. S. Savran), İstanbul: Metis Yayınları.

Hoffman, S. (2014). "Küreselleşmelerin Çarpışması Yeni Bir Paradigma mı?”, (Çev. M. C. Çelebi), (Ed. D. Held ve A. McGrew), Küresel Dönüşümler Büyük Küreselleşme Tartışması, Ankara: Phoenix Yayınevi: 133-139.

Huber, E. ve Stephens, J. D. (2013). "Küresel Kapitalizmde Devletin Ekonomik ve Sosyal Politikası”, (Çev., O. Sevimli ve S. Torlak), (Ed. T. Janoski, R. Alford, A. Hicks ve M. A. Schwartz), Siyaset Sosyolojisi, Ankara: Phoenix Yayınları: 791819.

Jessop, B. (1994). "The Transition to Post-Fordism and the Schumpeterian Workfare State", (Ed. R. Burrows ve B. Loader), Towards a Post-Fordist Welfare State, London and New York: Routledge: 13-37.

Jessop, B. (1996). "Post-Fordism and the State" (Ed. B. Greve), Comparative Welfare Systems, Basingstoke: Macmillan: 165-184.

Jessop, B. (2000)." From the KWNS to the SWPR", (Ed. G. Lewis, S. Gewirtz ve J. Clarke), Rethinking Social Policy, London: Sage: 171-184.

Kashwan, P., Maclean, L. M. ve Garcia-Lopez, G. A. (2019). “Rethinking Power and Institutions in the Shadows of Neoliberalizm", World Development, Vol. 120: 133-146.

Kazgan, G. (2009). Tanzimat'tan 21. Yüzyıla Türkiye Ekonomisi. İstanbul: İstanbul Bilgi Üniversitesi Yayınları.

Kennedy, P. (2005). Büyük Güçlerin Yükseliş ve Çöküşleri 16. Yüzyıldan Günümüze Ekonomik Değişim ve Askeri Çatışmalar, (Çev. B. Karanakçı), İstanbul: Türkiye İş Bankası Kültür Yayınları.

Keohane, R. O. (1984). After Hegemony Cooperation and Discord in the World Political Economy. Princeton: Princeton University Press.

Keohane, R. O. ve Nye, J. S. (2014). “Küreselleşme: Yeni Olan Ne? Olmayan Ne? (Ve Ne Olmuş Yani)”, (Çev. M. C. Çelebi), (Ed. D. Held ve A. McGrew), Küresel Dönüşümler Büyük Küreselleşme Tartışması, Ankara: Phoenix Yayınevi: 97106. 149.

Koyuncu, B. (2006). “Küreselleşme ve Türk İşadamları Derneği: TÜsiAD Örneği”, Uluslararası ilişkiler, C. 3, S. 9: 125-

Kydland, F. E. ve Prescott, E. C. (1977). "Rules rather than Discretion: The Inconsistency of Optimal Plans", The Journal of Political Economy, Vol. 85, No. 3: 479-492.

Lall, S. (2009). "Sanayileşme Stratejisini Yeniden Düşünmek: Küreselleşme Çağında Devletin Rolü”, (Çev., T. Koldaş), (Ed. F. Şenses), Neoliberal Küreselleşme ve Kalkınma Seçme Yazılar, İstanbul: Illetişim Yayınları: 459-508. 46.

Lucas, R. E. (1976). “Econometric Policy Evaluation: A Critique”, Journal of Monetary Economics, Vol. 1, No. 2: 19-

Mann, M. (1993). The Sources of Social Power Cilt 2. Cambridge: Cambridge University Press.

March, J. G. ve Olsen, J. P. (1998). "The Institutional Dynamics of International Political Orders", International Organization, Vol. 52, No. 4: 943-969. 


\section{Eskişehir Osmangazi Üniversitesi İktisadi ve İdari Bilimler Fakültesi Dergisi}

Mayr, A. (2015). “Institutional Discourse”, (Ed. D. Tannen, H. E. Hamilton ve D. Schiffrin), Handbook of Discourse Analysis, West Sussex: Wiley Blackwell: 755-774.

McMicheal, P. (2013). “Küreselleşme”, (Çev. G. Küçükören), (Ed. T. Janoski, R. Alford, A. Hicks ve M. A. Schwartz), Siyaset Sosyolojisi, Ankara: Phoenix Yayınevi: 765-790.

McNamara, K. (2002). "Rational Fictions Central Bank Independence and the Social Logic of Delegation", West European Politics, Vol. 25, No. 1: 47-76.

McNamara, K. R. (2008). "A Rivalry in the Making? The Euro and International Monetary Power", Review of International Political Economy, Vol. 15, No. 3: 439-459.

Meyer, J. W., Boli, J., Thomas, G. M. ve Ramirez, F. O. (1997). "World Society and the Nation State", American Journal of Sociology, Vol. 103, No. 1: 144-181.

Meyer, M. (2001). "Between Theory, Method and Politics: Positioning of the Approaches to CDA", (Ed. R. Wodak ve M. Meyer), Methods of Critical Discourse Analysis, London: Sage: 14-31.

Miller, G. P. (1998). "An Interest Group Theory of Central Bank Independence", The Journal of Legal Studies, Vol. 27, No. 2: 433-453.

Mishkin, F. S. (2009). "Why We Sholdn't Turn our Backs on Financial Globalization?", IMF Staff Papers, Vol. 56, No. 1: 139-170.

Mundell, R. A. (1962). "The Appropriate Use of Monetary and Fiscal Policy for Internal and External Stability", International Monetary Fund, Vol. 9, No.1: 70-79.

Mundell, R. A. (1963). "Capital Mobility and Stabilization under Fixed and Flexible Exchange Rates", The Canadian Journal of Economics and Political Science, Vol. 29, No. 4: 475-485.

Mundell, R. A. (1964). "A Reply: Capital Mobility and Size", The Canadian Journal of Economics and Political Science, Vol. 30, No. 3: 421-431.

O'Mahony, A. (2007). "Escaping the Ties that Bind Exchange Rate Choice under Central Bank İndependence", Comparative Political Studies, Vol. 40, No. 7: 808-831.

Öniş, Z. ve Şenses, F. (2009). "Post-Washington Mutabakatı'nı Yeniden Düşünmek”, (Ed.F. Şenses), Neoliberal Küreselleşme ve Kalkınma Seçme Yazılar, İstanbul: İletişim Yayınları: 347-385.

Özdemir, A. M., Aykut, E., Sune, E. ve Uğurlu, G. (2015). Türk Dış Politikasının Ekonomi Politiği: Büyük Sorulara Küçük Yanıtlar. Ankara: İmge Kitabevi.

Pamuk, Ş. (2004). “Karşılaştırmalı Açıdan Türkiye'de İktisadi Büyüme 1880-2000”, (Ed. A. H. Köse, F. Şenses ve E. Yeldan), İktisat Üzerine Yazılar I: Küresel Düzen: Birikim, Devlet ve Sınıflar Korkut Boratav'a Armağan, İstanbul: İletişim Yayınları: 383-398.

Parkinson, C. N. (1957). Parkinson's Law and Other Studies in Administration, (Dü. R. C. Osborn,), New York: Balletatine Books.

Posen, A. (1998). "Central Bank Independence And Disinflationary Credibility: A Missing Link", Oxford Economic Papers, Vol. 50: 335-359.

Putnam, L. L. ve Fairhurst, G. L. (2001). “Discourse Analysis in Organizations”, (Ed. F. M. Jablin ve L. L. Putnam), Sage Handbook of Organizational Communication, London: Sage: 78-136).

Rodrik, D. (1997). Has Globalization Gone too Far?, Washington D.C.: Institute for International Economics.

Rodrik, D. (2009). “iktisat Reformlarını Anlamak”, (Çev. S. Görüş), (Ed. F. Şenses), Neoliberal Küreselleşme ve Kalkınma Seçme Yazılar, İstanbul: İletişim Yayınları: 177-233.

Rodrik, D. (2011). Küreselleşme, Küresel Piyasalar Devlet ve Demokrasi Neden Birlikte Var Olamazlar?, (Çev., B. Aksu), Ankara: Efil Yayınevi.

Saad-Filho, A. (2018). "Neoliberal Geçişte Para Politikası: Keynescilik, Monetarizm ve Enflasyon Hedeflemesinin Siyasi İktisat Açısından Eleştirisi", (Çev., C. Cemgil), (Ed. R. Albitton, B. Jessop ve R. Westra), Siyasi İktisat ve Küresel Kapitalizm: 21. Yüzyıl, Bugün ve Yarın, İstanbul: İstanbul Bilgi Üniversitesi Yayınları: 101-135.

Simone, P. ve Guillen, M. F. (2005). "Globalization Pressures and the State: The Worldwide Spread of Central Bank İndependence", American Journal of Sociology, Vol. 110, No. 6: 1764-1802.

Skocpol, T. (1985). "Bringing the State Back in: Strategies of Analysis in Current Research", (Ed. P. Evans, D. Rueschemeyer ve T. Skocpol), Bringing The State Back, Cambridge: Cambridge University Press: 3-37.

Slobodian, Q. (2020). Küreselciler: İmparatorluğun Sonu ve Neoliberalizmin Doğuşu, (Çev., A. F. Yıldırım), İstanbul: Vakıf Bank Kültür Yayınları. 
Sönmez, S. (2009). "Türkiye Ekonomisinde Neoliberal Dönüşüm Politikaları ve Etkileri”, (Ed. N. Mütevellioğlu ve S. Sönmez), Küreselleşme, Kriz ve Türkiye'de Neoliberal Dönüşüm, İstanbul: İstanbul Bilgi Üniversitesi Yayınları: 25-75.

Stiglitz, J. E. (2009). “Küreselleşen Dünyada Kalkınma Politikaları”, (Çev., E. Ö. Kan), (Ed. F. Şenses), Neoliberal Küreselleşme ve Kalkınma Seçme Yazılar, İstanbul: İletişim Yayınları: 281-306.

Tavlas, G. S. (1993). "The 'New' Theory of Optimum Currency Areas”, The World Economy, Vol. 16, No. 6: 663-685.

Tok, N. (2014). "Yeni Sağ, Türkiye ve Adalet ve Kalkınma Partisi”, (Ed. N. Tok, M. Özel ve A. V. Koçal), Yeni Sağ, Küreselleşme ve Türkiye Türkiye’nin Akpartili Yılları, Ankara: Orion Kitabevi: 129-160.

TÜSIAD (1990). 1990 Yılına Girerken Türk Ekonomisi. Yayın No: TÜSIAD-T/90.1.131. Ocak. İstanbul.

TÜSIAD (1992). 1992 Yılına Girerken Türk Ekonomisi. Yayın No: TÜSIAD-T/92.1.149. Ocak. İstanbul.

TÜSIAD (1992). 100 Günde Türkiye Ekonomisi. Yayın No: TÜSiAD-T/92,4-151. Nisan. İstanbul.

TÜSiAD (1992). 21. Yüzyıla Doğru Türkiye: Geleceğe Dönük Bir Atılım Stratejisi. Yayın No: TÜSiAD-T/92.11.155. Kasım. İstanbul.

TÜSIAD (1997). 1997 Yılına Girerken Türk Ekonomisi. Yayın No: TÜSiAD-T/97, 204. Ocak. İstanbul.

TÜSIAD (2021). Hakkında. https://tusiad.org/tr/tusiad/hakkinda (Erişim tarihi: 28/01/2021).

TÜSIAD (2021). 45.yıl. http://tusiad.org/45-yil/ (Erişim tarihi: 28/01/2021).

Van Dijk, T. A. (1993). "Principles of Critical Discourse Analysis”, Discourse ve Society, Vol. 4, No. 2: 249-283.

Van Dijk, T. A. (2001). "Multidisciplinary CDA: A Plea for Diversity”, (Ed. R. Wodak ve N. Meyer), Methods of Critical Discourse Analysis, London: Sage: 95-120.

Van Dijk, T. A. (2008). Discourse and Context: A Sociocognitive Approach. Cambridge: Cambridge University Press.

Van Dijk, T. A. (2009). Society and Discourse: How Social Contexts Influence Text and Talk. Cambridge: Cambridge University Press.

Van Dijk, T. A. (2015). "Critical Discourse Analysis", (Ed. D. Tannen, H. E. Hamilton ve D. Schiffrin), Handbook of Discourse Analysis, West Sussex: Wiley Blackwell: 466-485.

Van Leeuwen, T. (2008). Discourse and Practice: New Tools for Critical Discourse Analysis. Oxford: Oxford University Press.

Van Leeuwen, T. (2015). "Multimodality”, (Ed. D. Tannen, H. E. Hamilton ve D. Schiffrin), Handbook of Discourse Analysis, West Sussex: Wiley Blackwell: 447-465.

Vico, G. (2007). Yeni Bilim, (Çev., S. Ö. Akkaş), Ankara: Doğu-Batı Yayınları.

Wagenberge, E. V. (2009). "Washington Mutabakatı'ndan Washington Sonrası Mutabakata: Kalkınma Yanılsamaları", (Çev., E. Karaçimen), (Ed. F. Şenses), Neoliberal Küreselleşme ve Kalkınma Seçme Yazılar, İstanbul: İletişim Yayınları: 307-345.

Wallerstein, I. (2005). Dünya Sistemleri Analizi: Bir Giriş, (Çev. E. Abadoğlu ve N. Ersoy) İstanbul: Aram Yayıncılık.

Webb, M. C. (1991). "International Economic Structures, Government Interests, and International Coordination of Macroeconomic Adjustment Policies", International Organization, Vol. 45, No. 3: 309-342.

Williamson, J. (1993). "Democracy and the 'Washington Consensus'”, World Development, Vol. 21, No. 8: 13291336.

Williamson, J. G. (2002). Winners and Losers over Two Centuries of Globalization. NBER Working Paper Series. No: w9161. September.

Wodak, R. (2001a). "What CDA is about a Summary of its History, Important Concepts and its Concepts", (Ed. R. Wodak ve M. Meyer), Methods of Critical Discourse Analysis, London: Sage: 1-13.

Wodak, R. (2001b). "The Discourse-Historical Approach", (Ed. R. Wodak ve M. Meyer), Methods of Critical Discourse Analysis, London: Sage: 63-94.

Wodak, R. ve Reisigl, M. (2001). Discourse and Racism. (Ed. D. Tannen, H. E. Hamilton ve D. Schiffrin), Handbook of Discourse Analysis, West Sussex: Wiley Blackwell: 576-596.

Yeldan, E. (2013). Küreselleşme Sürecinde Türkiye Ekonomisi: Bölüşüm, Birikim ve Büyüme, İstanbul: İletişim Yayınları.

Yenal, O. (2003). Cumhuriyetin İktisat Tarihi, İstanbul: Homer Kitabevi. 


\section{Extended Summary}

\section{Neoliberalism, Central Bank Independence and the Role of Pressure Groups}

This study examines the attitude of pressure groups in Turkey on central bank independence policy, which is supported by neoliberalism, a project to reconstitute the world system. Neoliberalism asserts that the state must relinquish from the economy, substituted with the market mechanism, and the market must be governed by independent supreme boards. Hence, it claims that the CB which directs the money market must also be independent. According to this approach, independent $C B$ must adopt targeting of price stability and control of inflation around neutral money conception. There is a fundamental conflict between independent central bank idea, which prioritizes price stability policies, and social state idea, which must protect the general interest of society. In this context, the pressure groups which consist of outward-oriented sectors, financial sector, and capital owners who support CB independence play a critical role.

Because of these thoughts, it is sought to answer the questions about 'What is the attitude of TÜSIAD towards CB independence? What kind of discourses did TÜSIAD use? Do such attitudes and discourses have a relationship with neoliberal ideas? Why do pressure groups such as TÜSIAD defend and support central bank independence?

Neoliberalism supports the independence of the CB to reduce uncertainty in the future (Lucas, 1976; Kydland \& Prescott, 1977; Barro \& Gordon, 1983), to gain credibility in international markets (Tavlas, 1993: 676), to stabilize the economy (Bernhard et al., 2002: 705; Corden, 2003: 26-27; O'Mahony, 2007: 809) and to achieve low inflation rate (Alesina, 1988; Grilli, et al., 1991; Cuikerman, 1992; Cuikerman, et al., 1992; Cukierman \& Webb, 1995). The independence of central banks leads to a shift in power among social actors (Skocpol, 1985; Cox, 1992: 31; Guillen \& Polillo, 2005: 1766). The main reason for this is both social and political powers create that money, and there is a political order reflecting social demands behind it (Cohen, 1998: 12-13; McNamara, 2008: 441; Gilpin, 2011: 152). Therefore, CB independence will directly affect the economic and social power of local pressure groups. Since each pressure group is affected differently by central bank independence, the attitude of pressure groups towards CB independence may differ (Goodman, 1991: 330; Haggard \& Kaufmann, 1995: 7;). The coalition among pressure groups and between pressure groups and politicians may be dissolved due to unexpected inflation resulting from political choices. Sectors that will produce in the country and be affected more by the economic and political conditions in the country, support that governments should be effective in monetary policy. Import substitution sectors, sectors that produce non-tradable goods, and the labor class oppose the management of monetary policy towards technocratic structures. On the other hand, groups operating in open economic conditions and more affected by the developments in the world economic system prefer neutral money and monetary policy defined by rules and precise relations. Exportoriented sectors, international investors, banking and finance sector, and capital class support the independent $C B$, which is governed by technocrats, independent of politics, and whose primary priority is inflation targeting. (Miller, 1998: 435; Bearce, 2003: 378).

In this study, TÜSIAD (Turkish Industry and Business Association), which includes representatives of exportoriented companies and the banking and finance sector, was selected as a pressure group as the most important representative of the capitalist class in Turkey. The reports published by TÜsiAD were analyzed as analysis material. The purposive sampling method was used the selection of TÜSIAD as the pressure group and the reports which TÜSIAD published. These reports were analyzed by Fairclough's (2001, 2002, 2003, 2005, 2013) critical discourse analysis method. Fairclough's $(2001 ; 2003 ; 2013)$ ESA model consists of three stages. The first stage is the definition of the text. In the second stage, the text is interpreted. The stage in which the text is explained is the third stage. In this regard, the statements on $\mathrm{CB}$ independence in the reports were analyzed by discourse analysis of the text, intertextual analysis, and contextual analysis. The findings show that TÜSIAD defends and supports CB's independence by justifying its compliance with the neoliberal system, integration with western developed countries, political instabilities, and price stability.

Since the market order to be fully established in the world system, neoliberalism asserts that states must undertake institutional transformation and autonomous institutions must prevail in economic policies. While states comply with the neoliberal structure, they tend to obtain the legitimacy of their regimes in the market via institutional transformations, not politics. The most critical institutional transformation to gain the confidence of the market and ensure stability in macroeconomic policies is to make central banks independent from politics. To realize this transformation and adapt to the neoliberal structure, pressure groups dominated by the private sector try to convince politicians and society. TÜSIAD, which is the most influential pressure group in Turkey and defends harmony with the world system every period, has supported the central bank's independence. TÜsiAD has claimed that neoliberal policies, which are compatible with the Washington Consensus should be implemented, and the central bank should be independent since the $90 \mathrm{~s}$. Therefore, the reports published by TÜSIAD are examined, it is seen that $C B$ 
independence is emphasized to ensure price stability and prevent public deficits. It tried to convince political, economic, and social actors, arguing that the disadvantage of competition in international markets will be prevented and credibility will be gained thanks to the independent $C B$, which prevents economic instability, is not affected by political instability, and is managed by technocrats. As a result of these considerations, it is concluded that TÜSiAD played an active role as a pressure group in the independence of the CB. 